\title{
Ylide Ligands
}

Esteban P. Urriolabeitia

Department of Organometallic Compounds, Instituto de Ciencia de Materiales de AragónICMA, CSIC- Universidad de Zaragoza, c/Pedro Cerbuna 12, E-50009 Zaragoza, Spain.

esteban@unizar.es

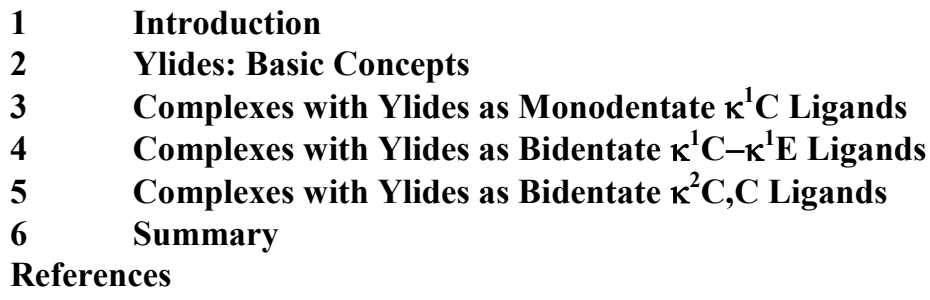

Abstract The use of ylides of P, N, As or S as ligands toward transition metals is still a very active research area in organometallic chemistry. This fact is mainly due to the nucleophilic character of the ylides and to their particular bonding properties and coordination modes. They can behave as monodentate or bidentate -chelate or bridging- species, they can be used as chiral auxiliary reagents, they are interesting reaction intermediates or useful starting materials in a wide variety of processes, etc. The most interesting bonding properties, structural features and applications of these versatile compounds will be covered in this chapter.

Keywords ylide, phosphorus, nitrogen, sulfur, transition metal

\begin{tabular}{|c|c|}
\hline \multicolumn{2}{|l|}{ Abbreviations } \\
\hline acac & acetylacetonate \\
\hline COD & 1,5-cyclooctadiene \\
\hline $\mathrm{Cp}$ & cyclopentadienyl \\
\hline $\mathrm{Cp}^{*}$ & pentamethylcyclopentadienyl \\
\hline dipp & diisopropylphenyl \\
\hline dmba & $\mathrm{C}_{6} \mathrm{H}_{4} \mathrm{CH}_{2} \mathrm{NMe}_{2}-\mathrm{C}^{2}, \mathrm{~N}$ \\
\hline $\operatorname{dmgH}$ & dimethylglyoxime mono anion \\
\hline dppm & $\mathrm{Ph}_{2} \mathrm{PCH}_{2} \mathrm{PPh}_{2}$, bis(diphenylphosphino)methane \\
\hline dppe & $\mathrm{Ph}_{2} \mathrm{PCH}_{2} \mathrm{CH}_{2} \mathrm{PPh}_{2}$, bis(diphenylphosphino)ethane \\
\hline napy & 1,8-naphthyridine \\
\hline $\mathrm{NHC}$ & $\mathrm{N}$-Heterocyclic Carbenes \\
\hline PPN & $\mathrm{Ph}_{3} \mathrm{P}=\mathrm{N}=\mathrm{PPh}_{3}$ \\
\hline OAc & acetate \\
\hline py & pyridine \\
\hline THF & tetrahydrofurane \\
\hline tht & tetrahydrothiophene \\
\hline
\end{tabular}




\section{Ylide Ligands}

\section{Introduction}

This chapter is devoted to the use of ylides as ligands. Probably it is unnecessary to spend many sentences to introduce the ylides; almost 6000 papers indexed at the Web Of Knowledge ${ }^{\odot}$ (2009 July), more than 81000 cites and a " $h "$ index of 82 are certainly good credentials to show the impressive importance of these compounds. The main part of this work concerns the chemistry performed on the Wittig reaction [1], but very important contributions have been developed around the use of ylides as ligands towards transition metals [2]. In this chapter we will show the most interesting aspects of the binomial ylides-ligands, applied to organometallics complexes. The different synthetic approximations to complexes with ylides in several bonding modes will be discussed, as well as their main structural features. Related aspects such as different reactivity patterns or applications (for instance, as source of other ligands or in catalytic processes) will also be covered.

\section{2}

\section{Ylides: Basic Concepts}

Ylides, by definition, are nucleophiles. Probably the most complete definition has been given by AW Johnson [2], who stated that "an ylide is a carbanion directly bonded to a heteroatom with a high degree of formal positive charge, this charge arising from the number of sigma bonds between the heteroatom and its substituents". Formally, ylides could be represented in two extreme canonical forms, one without formal charges (ylene) and one zwitterionic (ylide), both shown in Scheme 1. In practice, the chemical behaviour of the ylides can be explained just considering the polar ylide form. The presence of a negative charge at the ylidic carbanionic center is the source of the nucleophilic behaviour of the ylides and, hence, the origin of their ability to behave as ligands. The nature of the substituents $R_{1}$ and $R_{2}$ could allow the delocalization of the charge through auxiliary functional groups, and then the ylides can be classified in three main groups: non stabilized, semi-stabilized and stabilized.

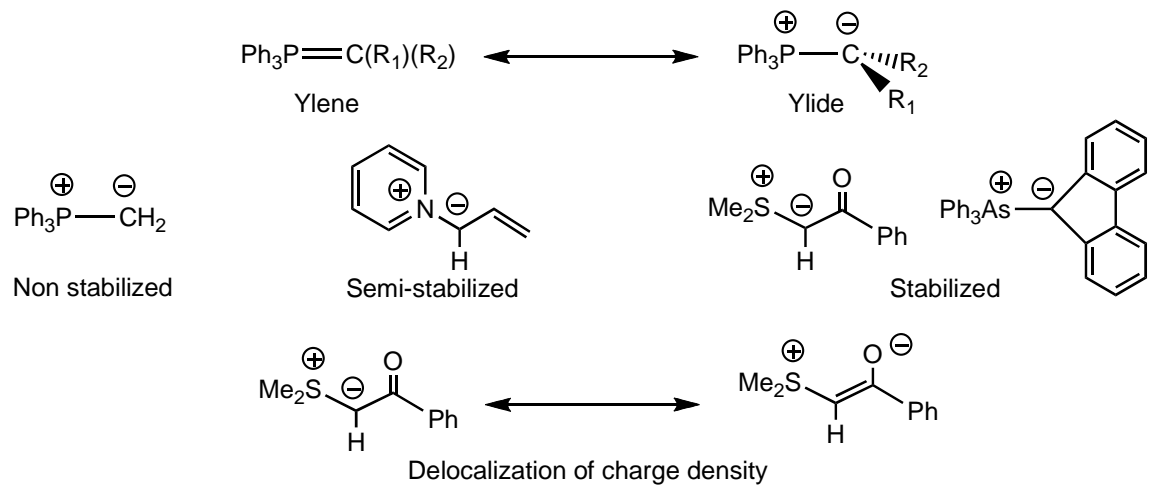

Scheme 1. General Features of Ylides 


\section{Ylide Ligands}

This stability is referred to the reactivity of the carbanionic center. It is clear that a keto (or a cyano) group is able to delocalize very efficiently the negative charge, this fact providing air- and moisture-stable ylides. In addition, these stabilized species are the less nucleophilic reagents. The opposite behaviour is found when the two substituents are $\mathrm{H}$ atoms or alkyl groups: most of the ylidic charge resides at the carbon atom, therefore these ylides are strong nucleophiles and very reactive species, and unstable towards air or moisture. Between the two extremes, as a function of $R_{1}$ and $R_{2}$, we find a continuous of more or less stabilized situations and, hence, of more or less nucleophilic reagents, with allyl, vinyl or phenyl as substituents.

Ylides in which the heteroatom is $\mathrm{N}, \mathrm{P}, \mathrm{As}, \mathrm{S}$ or Se are well known. Other ylides containing $\mathrm{Sb}, \mathrm{Bi}, \mathrm{O}, \mathrm{Te}, \mathrm{I}$ or $\mathrm{Br}$ are also known, but they are rarely used as ligands since they are very unstable, and they will not be treated here. The synthesis of the ylides is achieved through several preparative methods, most of which have been comprehensively reviewed [2-11]. The most relevant of them requires two steps, and involves the reaction of a halide with a $\mathrm{EZ}_{\mathrm{n}}$ nucleophile $\left(\mathrm{NR}_{3}, \mathrm{PR}_{3}, \mathrm{AsR}_{3}, \mathrm{SR}_{2}\right.$, etc) and subsequent dehydrohalogenation of the "onium" salt (method a) as represented in Scheme 2 [2-6]. This process has been reported in a wide variety of experimental conditions, using virtually all kind of solvents and bases (provided that they are compatible). The desilylation of some $\alpha-\mathrm{SiMe}_{3}$ onium salts (method $b$ ) is a useful alternative to the deprotonation method when competitive pathways to the ylide formation are operative $[2,3,7]$. The best desilylating agent seems to be the fluoride anion [7].

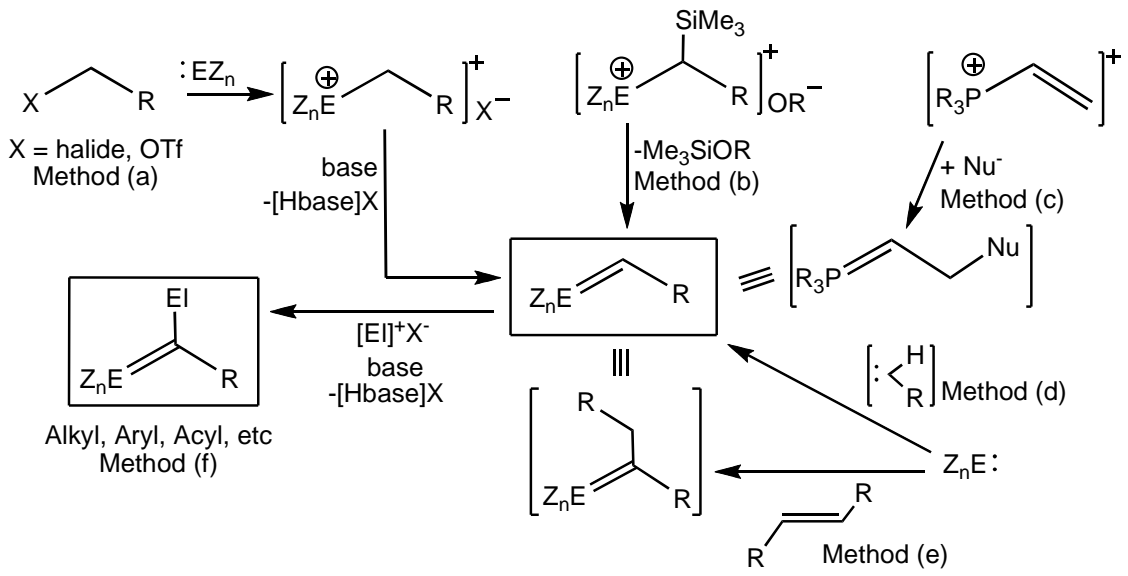

Scheme 2. Most common preparative methods for the synthesis of ylides

On the other hand, nucleophilic attack to the Schweizer's reagent -a vinyl phosphonium salt, method $\mathrm{c}-$ is also a very efficient synthetic method to prepare $\mathrm{P}$-ylides $[2,3,5,8]$. Further reactivity of these ylides gives very interesting derivatives [2]. The homolytic cleavage of the $Z_{n} E=C$ double bond should give, in 


\section{Ylide Ligands}

principle, a singlet carbene and the nucleophile $Z_{\mathrm{n}} \mathrm{E}$. Therefore, it is not surprising that the reaction bewteen a carbene and the corresponding nucleophile $\left(\mathrm{R}_{3} \mathrm{P}, \mathrm{R}_{3} \mathrm{~N}\right.$, $\mathrm{R}_{2} \mathrm{~S}$, etc) gives cleanly the expected ylide (method d) [2,3,4,9]. The carbene is usually stabilized as a diazo derivative. This method is specially representative in the case of sulfur ylides, and allows to consider the ylides as carbene transfer reagents. In fact, this is the case, as we will see later. Another useful method is the reaction of nucleophiles (phosphines, amines, sulfides, etc) with unsaturated substrates. Amongst them, alkenes and alkynes are the best choices (method e) due to the availability of different substrates $[2,5,8]$, which results in a large variety of possible structures. The cycloaddition reactions [10] and other more specific processes [11] have also been reviewed.

In addition, the functionalization of a pre-formed ylide is also a valuable synthetic procedure. The addition of an electrophile to single-substituted ylides (in other words, with a $\mathrm{H}$ atom at the ylidic $\mathrm{C} \alpha$ atom) gives the corresponding onium salts, which can be further deprotonated to give doubly-substituted ylides (method f) [2,5]. Alkylation, arylation or acylation processes at the $\mathrm{C} \alpha$ have been reported, amongst others, with the concomitant synthesis of the doubly substituted ylides. Not only the preparative methods specified, but also the bonding properties [12] of the ylides -mostly at the $\mathrm{E}=\mathrm{C} \alpha$ bond - and some interesting organic applications $[13,14]$ have been the subject of detailed revision works. In summary, the chemistry shown in Scheme 2 constitutes an useful set of tools able to provide tailored synthetic procedures to the obtention of a given ylide, whatever its structure.

Ylides can also be behave as ligands towards transition metals due to the presence of the negative charge, which could either be centered at the C $\alpha$ atom or more or less delocalized through the substituents. Ylides are not simply ligands, they are very good ligands and they have been frequently used as ancillary ligands in organometallic complexes. There are several reasons to understand this success. The deep knowledge of these systems, the variety of structural motifs and the number of different preparative methods, results of the development of the Wittig reaction, provides a set of available ligands than can be customized, and in which the steric and electronic requirements can be tuned easily. Moreover, some ylides (mainly the stabilized ylides) have several potential donor atoms, this fact conferring them a monodentated vs polydentate behaviour. A very interesting fact is that, as a function of the substituents, the $\mathrm{C}$ bonding of the ylide transforms the prochiral center on the free ylide in a stereogenic center in the complex, being the source of asymmetry (the $\mathrm{C} \alpha$ atom) bonded directly to the metal (that is, where things happen, for instance, in catalytic processes).

Although, in principle, the chemistry here reported should be centered on the "late" transition metals, sometimes we will jump the frontier between "late" and "middle" or "early" transition metal since this line could be more or less diffuse and could change as a function of the history. At least seven different coordination modes have been identified (I-VII, Scheme 3) as main bonding modes. In modes I and II the ylide behaves as neutral and monodentate, bonded exclusively through 
the $\mathrm{C} \alpha$ atom ( $\mathrm{KC}$ mode); this is the case for simple ylides and carbodiphosphoranes. Mode III cover the variants of a "metallated" ylide, that is, a situation in which the metal replaces a substituent of the ylide and transforms it into an anionic ligand.
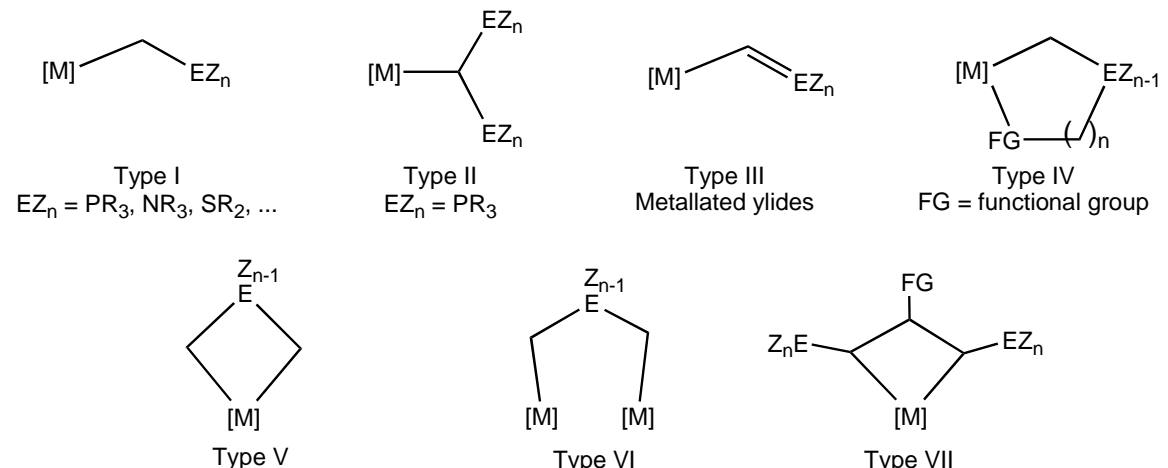

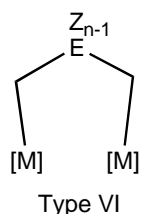<smiles></smiles>

Scheme 3 Typology of the complexes described as a function of the ylide

Mode IV represents the well known chelating bonding mode, one donor atom being the ylidic $\mathrm{C}(\kappa \mathrm{C})$ and the other an heteroatom $(\kappa \mathrm{E})$, while mode $\mathrm{V}$ presents the particular case of a chelate in which the two donor atoms are ylidic carbons of the same bisylide $\left(\kappa^{2}-\mathrm{C}, \mathrm{C}\right)$. Mode VI is the bridging version of type $\mathrm{V}$, and mode VII try to cover the chemistry of different types of bis-ylides. Both modes VI and VII are bonded through two ylidic carbon atoms.

Some particular aspects of the chemistry of ylides as ligands have been reviewed throughout the years [15-27]. The topics are quite specific in most cases, and the main part of them are treated comprehensively: non-stabilized ylides [15,16], Sylides [17], $\mathrm{Au}$ ylides and methanides [18], $\mathrm{Li}$ derivatives [19], $\mathrm{Pd}$ and $\mathrm{Pt}$ complexes [20-23], zwitterionic metallates [24], stabilized ylides [25] and applications [26,27] have been reported. We will try in the following sections to give a basic complementary point of view about the chemistry of ylides as ligands.

3

\section{Complexes with Ylides as Monodentate $\kappa^{1} \mathrm{C}$ Ligands}

The simplest method to coordinate an ylide to a transition metal is the reaction bewteen the free ylide and a metallic precursor with at least one coordinative vacant or a ligand easily removable. The highest ability to coordinate to the metal is shown by the non-stabilized ylides, but even their stabilized counterparts behave as good ligands. The first examples of metal-bonded ylides were Pd(II) and $\mathrm{Pt}(\mathrm{II})$ complexes. The starting materials were simple complexes as $\mathrm{MX}_{2} \mathrm{~L}_{2}$ or $\mathrm{Q}_{2}\left[\mathrm{MCl}_{4}\right]\left(\mathrm{X}=\right.$ halide; $\left.\mathrm{L}=\mathrm{SMe}_{2}, \mathrm{NCMe}, \mathrm{NCPh} ; \mathrm{Q}=\mathrm{Na}, \mathrm{Li}\right)$ or even the binary salts $\mathrm{MCl}_{2}$ [28-34]. Mono and dinuclear complexes (1) - (3), with one or two bonded ylides to each metal center, and in different geometries, were prepared and characterized as shown in Scheme 4. Dinuclear $\mathrm{Ni}(\mathrm{II})$ and $\mathrm{Co}(\mathrm{II})$ derivatives 


\section{Ylide Ligands}

similar to (3) have also been reported [35]. The ylide displaces the bromide ligand from the coordination sphere of the $\mathrm{Ni}(\mathrm{II})$ center in $[\mathrm{CpNiBrL}]$ giving cationic cyclopentadienyl Ni(II) derivatives (4) [36]. Similarly, Co(III) complex (5) can be obtained from $\left[\mathrm{CoMe}(\mathrm{dmgH})_{2}\left(\mathrm{SMe}_{2}\right)\right]$ by substitution of the sulfide group by the pyridinium ylide [37].

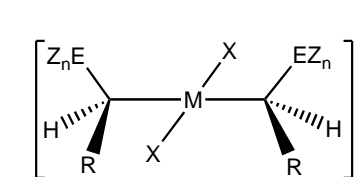

$$
\begin{aligned}
& \text { (1) trans and } \\
& \text { For (1) - (3): } \\
& \mathrm{M}=\mathrm{Pd}, \mathrm{Pt} ; \mathrm{X}=\mathrm{Cl} \\
& \mathrm{L}=\text { neutral ligand } \\
& \mathrm{EZ} \mathrm{S}_{\mathrm{n}}=\mathrm{SR}_{2}, \mathrm{PR}_{3},
\end{aligned}
$$

(7)

$E Z_{n}=S R_{2}, P R_{3}, S(O) R_{2}$

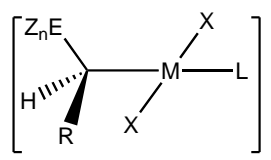

(2) trans and cis

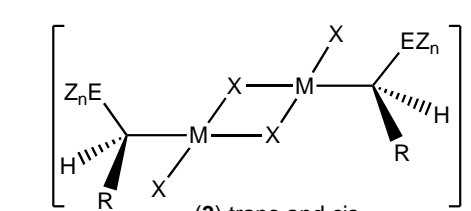

(3) trans and cis

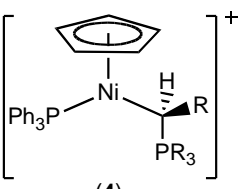

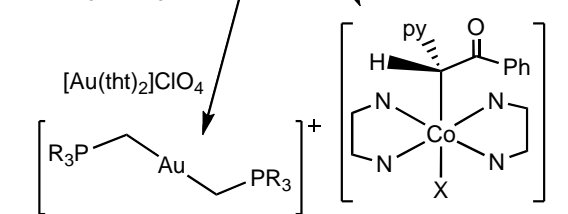

(5)

\section{Scheme 4 Synthesis of C-bonded ylide complexes by ligand displacement}

Complex (5) with $\mathrm{X}=\mathrm{Cl}$ can be obtained by oxidative addition of the pyridinium salts $\left[\mathrm{pyCH}_{2} \mathrm{C}(\mathrm{O}) \mathrm{Ph}\right] \mathrm{X}$ to the $\mathrm{Co}(\mathrm{II})$ derivative $\left[\mathrm{Co}(\mathrm{dmgH})_{2}\left(\mathrm{OH}_{2}\right)_{2}\right]$ [38]. We will discuss in some depth later the use of the stable onium salts as precursors of metal-bonded ylides. Further examples of ylide bonding by ligand displacement can be found in gold complexes. Au(I) and $\mathrm{Au}(\mathrm{III})$ derivatives (6) and (7) have been prepared by reaction of $\left[\mathrm{Au}(\mathrm{tht})_{2}\right] \mathrm{ClO}_{4}[39]$ or $\mathrm{Me}_{3} \mathrm{AuPR}_{3}$ [40] with nonstabilized ylides. In the first case the labile tht is removed, but in the second case a phosphine group, usually a strongly coordinated ligand, can be displaced.

The synthetic method outlined in the preceding paragraph has been by far the most employed preparative pathway, mainly in $\mathrm{Pd}(\mathrm{II})$ and $\mathrm{Pt}(\mathrm{II})$ complexes with stabilized ylides [41-47]. However, the C-bonding of the ylide could not be the final observed bonding mode in all cases. This fact is due to the presence of additional donor atoms, oxygen atoms in keto- or ester-stabilized ylides or nitrogen atoms in cyano-stabilized ylides. The O-bonding of a keto-stabilized ylide to a soft metal in complex (8) (Scheme 5) was observed by Usón et al. in 1985 [48]. The O-bonding was also observed in hard early metals ( $\mathrm{Ti}, \mathrm{Zr}, \mathrm{Nb})$ or in main group elements $(\mathrm{Si}, \mathrm{Sn})$ in high oxidation states, but this topic will not be treated here [21]. Further studies showed that stabilized ylides can behave as ambidentate ligands toward soft metals, bonding through the $\mathrm{C} \alpha$ atom or through 


\section{Ylide Ligands}

the heteroatom $(\mathrm{O}$ or $\mathrm{N})$ but not using the two donor atoms at the same time. The adoption of a particular bonding mode seemed to be dependent of several parameters. The first one is the nature of the ancillary ligands at the starting complex, mainly the ligand trans to the vacant site. The second one is the nucleophilicity of the ylidic carbon and the last, but not the least, are the steric requirements [21]. The coordination of the poorly nucleophilic ylide $\left[\mathrm{Ph}_{3} \mathrm{P}=\mathrm{CHC}(\mathrm{O}) \mathrm{Me}\right]$ to the solvate complex $[\mathrm{Pd}(\mathrm{dmba})(\mathrm{py})(\mathrm{THF})]^{+}$yields complex (9), in which the ylide is O-bonded trans to the palladated carbon [49], while the more nucleophilic ylide $\left[\mathrm{Ph}_{3} \mathrm{P}=\mathrm{CHCO}_{2} \mathrm{Me}\right]$ coordinates through the carbon atom giving (10) [50] (Scheme 5). It is very remarkable that $\mathrm{C}$-bonding in (10) occurs trans to the $\mathrm{N}$ atom of the $\mathrm{NMe}_{2}$ group, with concomitant migration of the py ligand to the position trans to the palladated carbon. However, the same nucleophilic ylide $\left[\mathrm{Ph}_{3} \mathrm{P}=\mathrm{CHCO}_{2} \mathrm{Me}\right]$ bonds through the oxygen atom when a phosphine ligand is blocking the position trans to the $\mathrm{N}$ atom, giving complex (11) [50]. A careful inspection of several examples [51-54] leads to the conclusion that the $\mathrm{O}$-coordination is produced trans to a soft $(\mathrm{C}$ or $\mathrm{P})$ atom, while $\mathrm{C}-$ coordination mainly occurs trans to a harder $(\mathrm{N})$ atom. Complex (12) is the paradigm of this selectivity on bonding modes and sites [53]: the $\mathrm{C}$-bonded ylide is found trans to the $\mathrm{N}$ atom while the $\mathrm{N}$-bonded ylide is trans to the palladated $\mathrm{C}$ atom. In spite of this puzzling appearance (Scheme 5), the consideration of the nature of the donor atoms and the antisymbiotic behaviour of the Pd center [55] provides a sensible explanation of the observed reactivity [21].

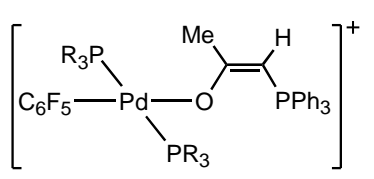

(8)

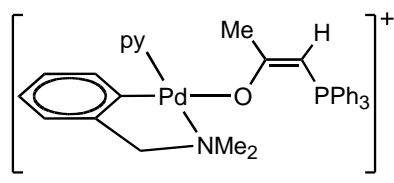

(9)

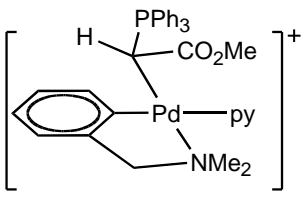

(10)

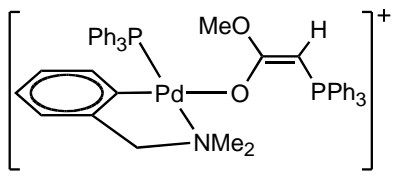

(11)<smiles>CN(C)[Pb](C#N)(Cc1ccccc1)Cc1ccccc1</smiles>

(12)

Scheme 5 Ambidentate (O vs $\mathrm{C}$ ) behaviour of stabilized ylides as ligands

The introduction of a second stabilizing group changes dramatically the reactivity of the ylides, since the $\mathrm{C} \alpha$ atom is no longer coordinated to the metal. Examples of doubly stabilized ylides are $(\text { Aryl })_{3} \mathrm{P}=\mathrm{C}\left[\mathrm{C}(\mathrm{O}) \mathrm{R}_{1}\right]\left[\mathrm{C}(\mathrm{O}) \mathrm{R}_{2}\right]$ or (Aryl $)_{3} \mathrm{P}=\mathrm{C}\left[\mathrm{C}(\mathrm{O}) \mathrm{R}_{1}\right]\left[\mathrm{C}\left(=\mathrm{NR}_{2}\right) \mathrm{R}_{3}\right]$, which only bind to the metal through the heteroatoms, not only in $\mathrm{Pd}$ or Pt centers [56,57], but also in other metals [58]. However, highly conjugated ketene ylide $\left[\mathrm{Ph}_{3} \mathrm{P}=\mathrm{C}=\mathrm{C}=\mathrm{O}\right]$ coordinates to $\mathrm{Pd}$ and $\mathrm{Pt}$ metallic centers through the $\mathrm{C} \alpha$ atom giving derivatives (13) [23,59-63], which keep the ketene character and react with nucleophiles to give simple ylides (14) 


\section{Ylide Ligands}

(Scheme 6). Another highly conjugated species, the Fehlhammer's ylide, bonds to $\mathrm{Pt}, \mathrm{Cr}$ or $\mathrm{W}$ using the isocyanide functional group, but can also acts as a $\mathrm{C}, \mathrm{C}-$ bridging ligand, for instance in (15) [64].

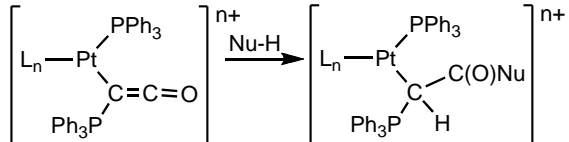

(13)<smiles>O=[N+]([O-])C=N[C@H](C=C[Co])c1ccccc1</smiles>

(15)

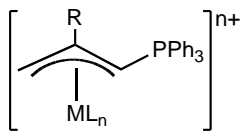

(16)

$\mathrm{ML}_{\mathrm{n}}=\mathrm{Pd}(\mu-\mathrm{Cl}) ; \mathrm{Pd}\left[\mathrm{Ph}_{3} \mathrm{P}=\mathrm{C}_{5} \mathrm{H}_{4}\right]$ $M L_{n}=P d\left(\eta^{3}-C_{3} H_{4} P^{2} h_{3}\right)$ $M L_{n}=\mathrm{M}(\mathrm{CO})_{5} ; \mathrm{M}=\mathrm{Mo}, \mathrm{W}$ $M L_{n}=\mathrm{PdCl}_{2} ; \mathrm{R}=\mathrm{H}, \mathrm{NMe}_{2}$

$\mathrm{L}_{\mathrm{n}}=$ allyl, $\mathrm{Cl}, \mathrm{C}_{2} \mathrm{H}_{4}, \mathrm{COD}$ $\mathrm{Nu}-\mathrm{H}=\mathrm{HNMe}_{2}, \mathrm{MeOH}, \mathrm{EtOH}$

\section{Scheme 6 Highly conjugated ylides and different bonding modes}

A special case shown in Scheme 6 is constituted by ylides having the allyl functional group as substituent [65-71]. These semi-stabilized ylides bonds $\eta^{3}$ to the metal, for instance in Pd, Mo or W complexes. The Pd complexes have been prepared by reaction of the allyl-phosphonium salt with $\mathrm{Na}_{2}\left[\mathrm{PdCl}_{4}\right]$ in presence of base [66,68-70] or by direct treatment of the free ylide with $\mathrm{PdCl}_{2}(\mathrm{COD})$ [71], while the Mo or $\mathrm{W}$ complexes have been synthesized by refluxing of the free ylide with the corresponding hexacarbonyl derivative [65,67]. In spite of the high reactivity of the allyl ylide, the resulting complexes (16) are very stable and, for instance, the bis(allyl) derivative does not eliminate the $\mathrm{CC}$ coupling product.

When the starting ylide is very unstable or when it is difficult to create vacant coordination sites, alternative synthetic methods have to be developed. One of the most popular is the so-called "acac method", which is particularly useful in gold complexes with stabilized ylides [72]. This method implies the reaction of an "onium" salt with an acetylacetonate derivative of $\mathrm{Au}(\mathrm{I})$, for instance [acacAuL] ( $\mathrm{L}=$ neutral ligand). The acid character of the methylene protons adjacent to the stabilizing group allows their easy extraction by the acetylacetonate, a weak base.

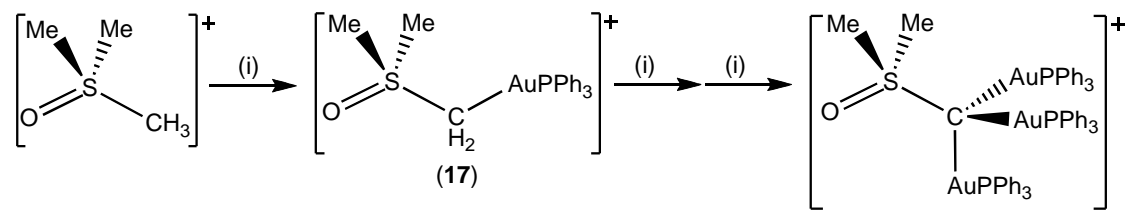

(i) + acacAuPPh $;$; - acacH (ii) $+\mathrm{ClO}_{4} \mathrm{AuPPh}_{3}$

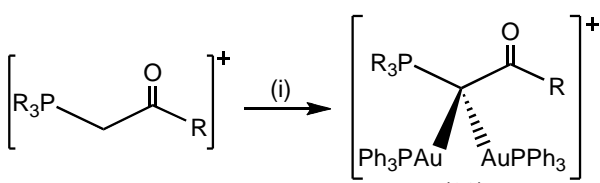

(20)

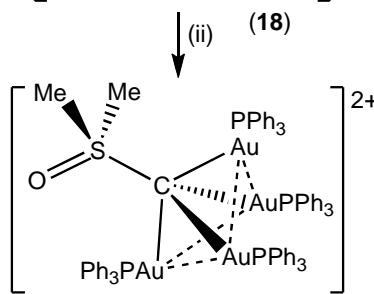

(19)

Scheme 7 Examples of ylide complexes obtained from the "acac method" 


\section{Ylide Ligands}

The "in situ" generated ylide binds to the metal center replacing the acac ligand, which is liberated under its protonated form. Examples are shown in Scheme 7. In some cases, even the methyl group can be sequentially deprotonated. Treatment of the sulfoxonium salt $\left[\mathrm{Me}_{3} \mathrm{SO}\right] \mathrm{ClO}_{4}$ with $[\mathrm{acacAuPPh}$ ] gives simple substitution product (17). Further reaction of (17) with $[\mathrm{acacAuPPh}$ ] allows the complete deprotonation of the methyl group and the synthesis of trinuclear (18), which can incorporate an additional $\left[\mathrm{AuPPh}_{3}\right]^{+}$cationic fragment and give an hypercoordinate ylidic $\mathrm{C} \alpha$ atom in (19) [73,74]. This method also applies for phosphonium salts allowing the synthesis of bridging carbene-like species (20) [75-77], although alternative methods have been reported [78].

A different approach to synthesize non-stabilized ylide complexes is the reaction of halomethyl-metallic precursors with the corresponding nucleophile $\mathrm{EZ}_{\mathrm{n}}$. This method is quite general and usually occurs in very mild reaction conditions. Platinum, rhodium, iron and palladium complexes (21)-(25) (Scheme 8) have been prepared, using phosphines [79-83], amines [84] or sulfides [85] as nucleophiles. Some of the most representative examples are shown in Scheme 8.

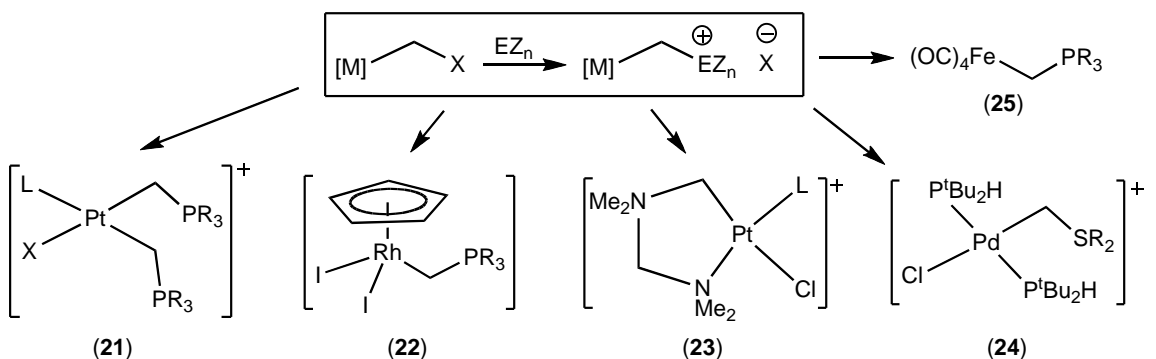

Scheme 8 Ylide complexes obtained from halomethyl derivatives

We have previously stated that an ylide could be considered the coupling product of a singlet carbene with a nucleophile. Therefore, it seems logical that the reaction of a metallic carbene with a nucleophile would give a metal bonded ylide and, in fact, this a quite useful method to prepare metallated ylides. Even more, in some cases coordinated ylides have been used as masked carbenes [85]. Complexes (26) (Scheme 9, M = Cr, W), which contain a pyridinium ylide, are conveniently prepared by reaction of the corresponding carbenes $\left[(\mathrm{CO})_{5} \mathrm{M}=\mathrm{C}(\mathrm{OEt}) \mathrm{R}\right]$ with $1,2-$ or 1,4 -dihydropyridines. During the reaction an unprecedented hydride transfer occurred [86], with concomitant ethanol elimination. Interestingly, (26) reacted with $\mathrm{PPh}_{3}$ giving (27) and free pyridine, in a clear example of exchange of nucleophiles and showing the reversibility of the ylide formation. In a similar way, pyridine reacts with rhenium carbenes [87] and with osmium porphyrin carbenes [88], the latter giving complexes (28). Stable iron ylide complexes (29) have been obtained by reaction of the very unstable carbene precursors $\left[\mathrm{CpFe}\left(=\mathrm{CH}_{2}\right) \mathrm{L}_{n}\right]$ with $\mathrm{PPh}_{3}[89,90]$. 


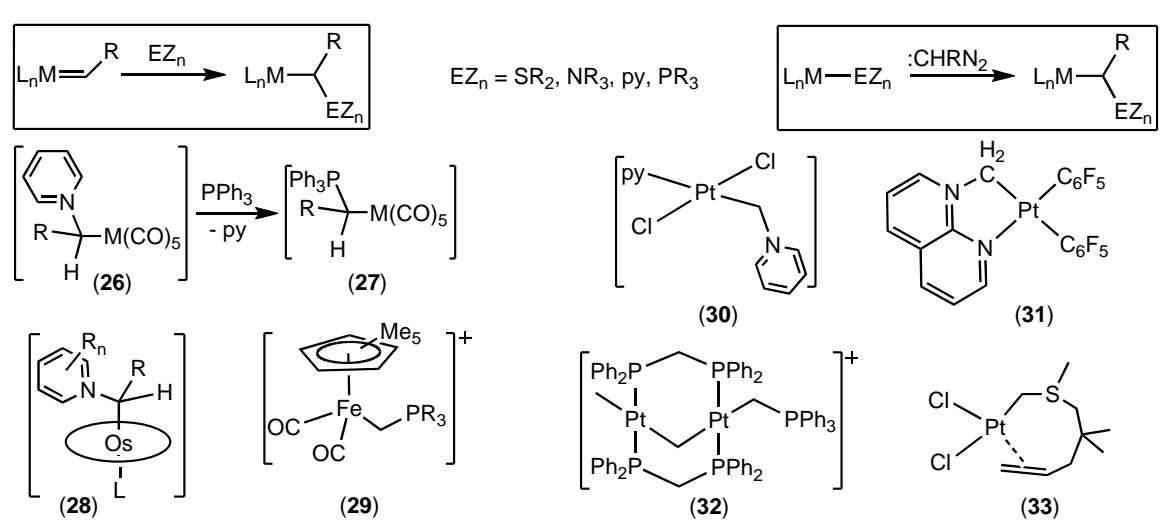

Scheme 9 Ylide complexes obtained from carbene derivatives

Closely related with the synthesis of ylides from carbenes is the use of ylides as carbene transfer reagents (CTR); that is, processes in which the ylide is cleaved homolitically, liberating the nucleophile and the carbene, which could remain both coordinated to the metal or not (Scheme 10). Diphosphirane (34) can be obtained from the diphosphene by reaction with sulfur ylide $\mathrm{Me}_{2} \mathrm{~S}(\mathrm{O})=\mathrm{CH}_{2}$, which behave as a carrier of the $\mathrm{CH}_{2}$ unit [95]. Recent work of Milstein et al. shows that sulfur ylides decompose in presence of $\mathrm{Rh}$ derivatives with vacant coordination sites affording Rh(I)-carbene complexes [96,97]. Complexes (35), (36) and (37) can be obtained from reaction of the ylide $\mathrm{Ph}_{2} \mathrm{~S}=\mathrm{C}(\mathrm{H}) \mathrm{Ph}$ with the adequate precursors, [(pincer) $\mathrm{RhN}_{2}$ ] [96], $\mathrm{RuCl}_{2}\left(\mathrm{PCy}_{3}\right)_{3}$ or $\mathrm{OsH}(\mathrm{Cl})(\mathrm{CO})\left(\mathrm{P}^{\mathrm{i}} \mathrm{Pr}_{3}\right)_{2}$ respectively [97].

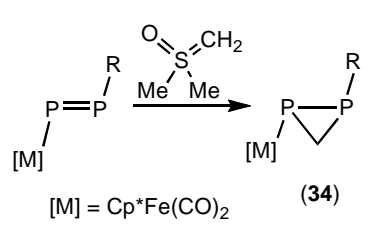

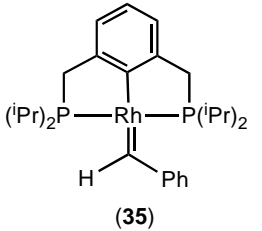

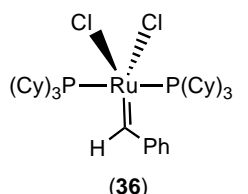

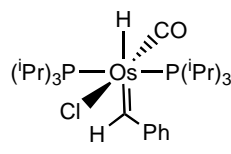

(37)

Scheme 10 Carbene complexes obtained from non stabilized ylides as CTR

The ability of ylides to behave as carbene transfer reagents has been extended recently to stabilized bis-ylides in Pd(II) or Pt(II) complexes, as shown in Scheme 11 [98]. As a function of the auxiliary ligands in the starting material, the carbene (38) is stable (both $\mathrm{R}$ are $\mathrm{C}_{6} \mathrm{~F}_{5}$ groups or a cyclometallated ligand) or evolves to the metallacyclopropane (39) (only one $\mathrm{C}_{6} \mathrm{~F}_{5}$ ligand in the starting compound).

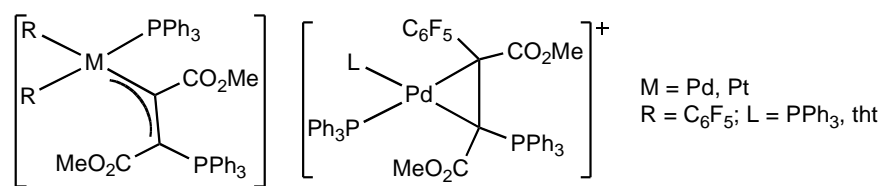

(38)

(39)

Scheme 11 Carbene complexes obtained from stabilized ylides as CTR 


\section{Ylide Ligands}

All synthetic methods described up to now (ligand desplacement, acac or halomethyl precursors, metal-bonded carbene + nucleophile, metal-bonded nucleophile + carbene) result in a metal-bonded ylide through the $\mathrm{C} \alpha$ atom. The reactivity of ylides toward metallic systems is, however, more rich than anticipated and other reaction pathways could compete with simple $\mathrm{C}$-bonding.

The first example is the clean reactivity of stabilized ylides towards simple palladium and platinum complexes containing alkene ligands, for instance COD. The COD ligand is easily removable from the coordination sphere of the $\mathrm{Pd}(\mathrm{II})$ or $\mathrm{Pt}(\mathrm{II})$ centers, and therefore the expected reactivity would be the displacement of the alkene by a more powerful ylidic nucleophile. However, the observed process is the addition of the ylide to the alkene giving $\sigma$-bonded alkyl derivatives (40) as those presented in Scheme 12 [99,100]. In the same way, platinum coordinated nitriles NCR' react with stabilized ylides to give iminophosphoranes (41) [101], imidoyl-ylides (42) [102], iminoylides (43) [103], while coordinated isonitriles CNR' (where R' is a functional group containing the ylide moiety) react also with ylides giving interesting carbenes $(44)[104,105]$.

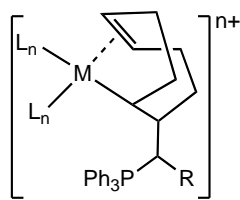

$(40)$

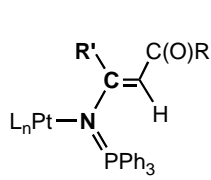

(41)<smiles></smiles>

(42)<smiles>O=C(NC1CCCCC1)C(=NC1CCCCC1)C(P)=[Pb]</smiles>

(43)

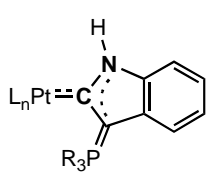

(44)

Scheme 12 Alternative reactivity of stabilized ylides with coordinated ligands

Going a little bit far away, there are a number of processes which are not strictly the coordination of ylides, but which are relevant enough to spend some paragraphs on describing them. This could probably give a better perspective of the potential of the ylides as versatile reagents

An interesting reactivity is that provided by the redox behaviour of the ylides. The firsts attempts to obtain stabilized ylides bonded to Pt(IV) were unsuccessful, since neutral complexes were employed and reduction to $\mathrm{Pt}(\mathrm{II})$ was observed instead [106]. The use of anionic Pt(IV) starting compounds avoided the redox process and stable $(\mathrm{PPN})\left[\mathrm{PtCl}_{4}\left(\mathrm{NH}_{2} \mathrm{R}\right)(\mathrm{ylide})\right]$ (45) complexes were prepared [107]. But the observed redox behaviour allowed the use of stabilized ylides as useful reducing agents under mild experimental conditions [108]. The coupling between $\mathrm{Pt}$-coordinated nitriles and nucleophiles (oximes, for instance) is a reaction controlled by the oxidation state of the metal: the coupling is achieved at the $\operatorname{Pt}(\mathrm{IV})$ center, but not (or not so successfully) at the $\operatorname{Pt}(\mathrm{II})$ center. Then, it is possible to propose a sensible synthetic pathway to obtain the coupling product starting from the more accessible Pt(II) complexes: (i) coordination of the nitrile to $\mathrm{Pt}(\mathrm{II})$; (ii) oxidation with $\mathrm{Cl}_{2}$; (iii) coupling at the $\mathrm{Pt}(\mathrm{IV})$ center; (iv) reduction with stabilized ylides [106]. This reaction scheme has been used very successfully. 


\section{Ylide Ligands}

Another impressive application of the keto-stabilized ylides is that derived from their reactivity towards $\mathrm{Ni}(0)$ complexes. The ylide $\left[\mathrm{Ph}_{3} \mathrm{P}=\mathrm{CHC}(\mathrm{O}) \mathrm{Ph}\right]$ reacts with $\mathrm{Ni}(\mathrm{COD})_{2}$ in presence of $\mathrm{PPh}_{3}$ to give, through an oxidative addition reaction, the phosphino-enolate complexes (46) [109]. Compound (46) shows an outstanding activity in the oligo- and polymerization of olefins, and also in the copolymerization of ethylene and $\mathrm{CO}$, and the reaction shown in the left part of Scheme 13 is a very easy and unexpensive synthesis of this type of complexes. Due to this exceptional activity and selectivity many variants of (46) have been prepared, in order to study the influence of the different reagents. Therefore, the phosphine, the substituents of the ylide, the solvent (and so on) have been changed. Far to be exhausted the interest in this type of complexes has not ceased, as it is evidenced by the number of contributions which still appear every year [26,110-112].<smiles>O=C(C=[PbH])c1ccccc1</smiles>

(46)<smiles></smiles>

Scheme 13 Applied reactivity of stabilized ylides

Finally, it should be also noted that a renewed interest on ylides as starting materials to prepare more elaborated products in a catalytic way has emerged. The process shown in the right half of Scheme 13 represents the selective ortho arylation of an iminopyridinium ylide, directed by the $\mathrm{CO}$ group, which affords adequate precursors of natural products $[113,114]$.

After this small walk-through the reactivity and applications of ylides, we come back to the $\kappa^{1} \mathrm{C}$ bonding mode, introducing new ligands: carbodiphosphoranes and cyclopentadienyl ylides.

Carbodiphosphoranes $\left[\mathrm{R}_{3} \mathrm{P}=\mathrm{C}=\mathrm{PR}_{3}\right]$ are a unique class of compounds, due to several reasons. The first noteworthy feature is that they have been described as "divalent carbon(0) compounds", that is, having two lone pairs located over the central carbon [115]. Similarly, a detailed analysis of the mixed phosphoniumsulfonium bisylide $\left[\mathrm{R}_{3} \mathrm{P}=\mathrm{C}=\mathrm{SR}_{2}\right]$ shows that the HOMO orbital corresponds to the in-plane lone pairs of the $\mathrm{C}$ atom [116]. The structures shown in Scheme 14 summarize this situation. These facts mean that the reactivity of these species would be strictly centered at the $\mathrm{C}$ center, which should behave as a strong nucleophile. In fact, the reaction of $\left[\mathrm{Ph}_{3} \mathrm{PCPPh}_{3}\right]$, the most known carbodiphosphorane, with several transition metals occurs always through the central carbon atom, giving structures as those shown in Scheme 14. Simple salts of coinage metals $[\mathrm{CuCl}$ or $\mathrm{AgCl}]$ or simple complexes $[\mathrm{AuCl}(\mathrm{CO})]$ react with $\left[\mathrm{Ph}_{3} \mathrm{PCPPh}_{3}\right]$ giving derivatives (47) [117]. The substitution of the chloride ligand by other anionic ligands is easily achievable [118]. $\mathrm{Ni}(\mathrm{CO})_{4}$ also reacts with $\left[\mathrm{Ph}_{3} \mathrm{PCPPh}_{3}\right]$ giving two different complexes (48) -dicarbonyl and/or tricarbonylas a function of the reaction solvent [119]. The dicarbonyl derivative seems to be 


\section{Ylide Ligands}

the first nickel complex with the $\mathrm{Ni}(\mathrm{CO})_{2}$ fragment linked to only one additional ligand, the diphosphorane in this case, resulting in an insaturated $16 \mathrm{e}^{-}$species. The presence of a high excess of electron density at the ylidic $\mathrm{C} \alpha$ atom allows the incorporation of a second metal center in some cases, for instance in the gold derivatives (49). Complexes (49) have been prepared by reaction of $\left[\mathrm{Ph}_{3} \mathrm{PCPPh}_{3}\right]$ with 2 equivalents of $\mathrm{ClAu}$ (tht) [120] or $\mathrm{MeAuPMe}_{3}$ [121], respectively. The reactivity of $\left[\mathrm{Ph}_{3} \mathrm{PCPPh}_{3}\right]$ with $\mathrm{Pt}(\mathrm{II})$ compounds is more complicated since, in addition to the simple $\kappa^{1} \mathrm{C}$-bonding, additional $\mathrm{CH}$ bond activation occurs. The reaction of 3 eqs of $\left[\mathrm{Ph}_{3} \mathrm{PCPPh}_{3}\right]$ with $\mathrm{I}_{2} \mathrm{Pt}(\mathrm{COD})$ gives complex (50) through orthoplatination of one phenyl ring and further activation of the $\mathrm{COD}$, which is transformed into a cyclooctadienyl ligand [122]. The own ylide acts as proton abstractor, forming $\left[\mathrm{Ph}_{3} \mathrm{PC}(\mathrm{H}) \mathrm{PPh}_{3}\right] \mathrm{I}$. In spite of the clear reactivity of $\mathrm{Pt}(\mathrm{II})$ complexes, the reaction of $\mathrm{Pt}(\mathrm{IV})$ species is more complicated [123] and gives mixtures of different types of orthometallated Pt(II) materials.

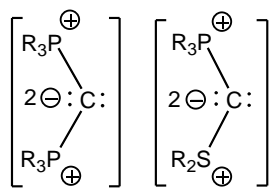<smiles>P=NC(=NCl)Pc1ccccc1</smiles>

$\mathrm{M}=\mathrm{Cu}, \mathrm{Ag}, \mathrm{Au}$

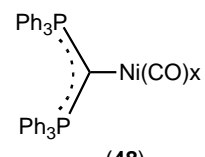

$(\mathbf{4 8})$
$\mathrm{x}=2,3$

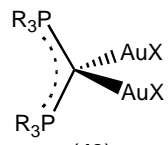

(49) $\mathrm{R}=\mathrm{Ph}, \mathrm{X}=\mathrm{C}$

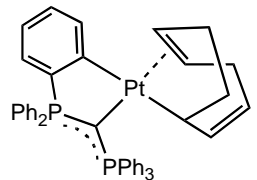

(50)

Scheme 14 Structures found for the carbodiphosphorane $\mathrm{Ph}_{3} \mathrm{P}=\mathrm{C}=\mathrm{PPh}_{3}$ (type II)

The reaction of metallic carbonyl derivatives towards carbodiphosphoranes is not always as simple as represented by the synthesis of complex (48). A further degree of complexity is introduced by the Wittig processes observed between $\mathrm{Mn}$ or Re carbonyls and $\left[\mathrm{Ph}_{3} \mathrm{PCPPh}_{3}\right]$. The reaction occurs with elimination of $\mathrm{OPPh}_{3}$ (typical residue of the Wittig reaction) and formation of a new phosphoniumalkynide ligand in complexes (51). This new ligand can be represented by two resonance forms, shown in Scheme 15, but the chemical behaviour of (51) is better explained taking into account the alkynyl form [124]. The different behaviour (Wittig vs substitution) seems to be strongly dependent of the reaction conditions, in addition to the nature of the metal center, since the same metal can show the two behaviours. Thus $\left[\mathrm{W}(\mathrm{CO})_{5}(\mathrm{THF})\right]$ reacts with $\left[\mathrm{Ph}_{3} \mathrm{PCPPh}_{3}\right]$ to give the substitution complex (48), but photolysis of $\left[\mathrm{W}(\mathrm{CO})_{6}\right]$ and $\left[\mathrm{Ph}_{3} \mathrm{PCPPh}_{3}\right]$ gives the Wittig product (51) (Scheme 15) [125].

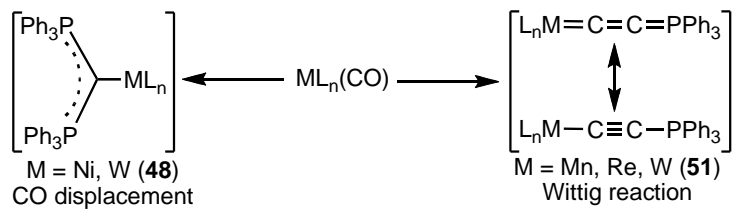

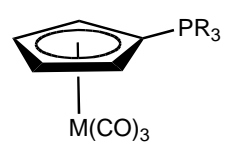

$\mathrm{M}=\mathrm{Cr}, \mathrm{Mo}, \mathrm{W}, \mathrm{Co}(\mathbf{5 2})$

Scheme 15 Reactivity of $\mathrm{Ph}_{3} \mathrm{P}=\mathrm{C}=\mathrm{PPh}_{3}$ and usual bonding modes of the Ramirez ylide 


\section{Ylide Ligands}

The cyclopentadienyl-ylide $\left[\mathrm{Ph}_{3} \mathrm{P}=\mathrm{C}_{5} \mathrm{H}_{4}\right]$, most commonly called Ramirez Ylide [126], and its derivatives $\left[\mathrm{R}_{3} \mathrm{P}=\mathrm{C}_{5} \mathrm{H}_{4}\right]$ are very stable species due to extensive delocalization of charge density through the $\mathrm{C}_{5} \mathrm{H}_{4}$ ring. Due to this fact they are almost chemically inert, and only recently a renewed interest allowed the synthesis and reactivity of a family of complexes (52), shown in Scheme 15 [127]. This is probably a very interesting field which merits to be developed.

The attack of nucleophiles to unsaturated ligands or functional groups bonded to metallic centers, exemplified in Scheme 9 (reaction of metallic carbenes with phosphines or pyridines) or in Scheme 15 (Wittig reaction) can be extended to a wide variety of reagents. Two main groups of reactions can be considered: (i) those in which the nucleophile is an ylide, and (ii) those in which the nucleophile is a phosphine (and less commonly other nucleophiles). Usually these reactions give metallated ylides (type III), that is, species in which the ylide substituents are metallic centers.

Examples of the first group of reactions are presented in Scheme 16. The ylide $\mathrm{Ph}_{3} \mathrm{P}=\mathrm{CH}_{2}$ reacts with the metal hexacarbonyls $\mathrm{M}(\mathrm{CO})_{6}(\mathrm{M}=\mathrm{Cr}, \mathrm{W})$ to give the metallated species (53) in two steps. The reaction begins with the addition of the nucleophilic ylidic $\mathrm{C} \alpha$ atom to the carbon atom of the $\mathrm{CO}$ ligand and subsequent $\mathrm{CC}$ coupling. The neutral intermediate $\left[(\mathrm{CO})_{5} \mathrm{MC}(\mathrm{O}) \mathrm{CH}_{2} \mathrm{PPh}_{3}\right]$ reacts with a second equivalent of $\mathrm{Ph}_{3} \mathrm{P}=\mathrm{CH}_{2}$, which deprotonates the $\mathrm{C}(\mathrm{O}) \mathrm{CH}_{2}$ group and gives the metallated ylide (53) together with the corresponding phosphonium salt [124]. This reactivity represents an alternative pathway to the displacement of CO and to the Wittig reaction. The iron complex (54) is obtained following strictly the same procedure, from cationic $\left[\mathrm{CpFe}(\mathrm{CO})_{2} \mathrm{~L}\right]^{+}$and 2 equivalents of $\mathrm{Ph}_{3} \mathrm{PCH}_{2}$ [128]. In some cases the addition occurs without additional deprotonation, as is the case of the attack of $\mathrm{Ph}_{3} \mathrm{PCH}_{2}$ to silylene derivatives to give (55) [129], but the usual trend is that, once the first ylide coordinates to the metal center, the excess of basic ylide promotes further deprotonations giving different species. Li and Sundermeyer have developed a very rich chemistry in $\mathrm{Ta}, \mathrm{Nb}, \mathrm{W}$ and $\mathrm{Re}$ derivatives $[130,131]$, and one example is shown in Scheme 16. The reaction of $\mathrm{Ph}_{3} \mathrm{PCH}_{2}$ with $\mathrm{CpTaCl}_{4}$ starts with the coordination of the ylide and formation of $\left[\mathrm{CpTa}\left(\mathrm{CH}_{2} \mathrm{PPh}_{3}\right) \mathrm{Cl}_{4}\right]$, which in turn reacts with 6 equivalents of $\mathrm{Ph}_{3} \mathrm{PCH}_{2}$ to give several intermediates as $\left[\mathrm{CpTa}\left(\equiv \mathrm{C}-\mathrm{PPh}_{3}\right) \mathrm{Cl}_{2}\right]$ and $[\mathrm{CpTa}(\equiv \mathrm{C}-$ $\left.\left.\mathrm{PPh}_{3}\right)\left(=\mathrm{C}(\mathrm{H}) \mathrm{PPh}_{3}\right) \mathrm{Cl}\right]$, and finally the methylidyne complex (56).
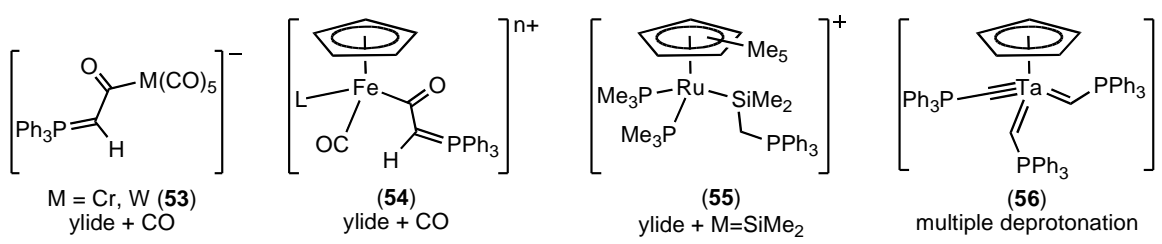

Scheme 16 Reactivity of $\mathrm{Ph}_{3} \mathrm{P}=\mathrm{CH}_{2}$ towards different unsaturated substrates 
Phosphines, as nucleophiles, add to many unsaturated substrates giving metallated ylides. Scheme 17 collects some representative examples of the addition of phosphines to carbyne complexes, giving (57) [132], to allenylidenes (58) [133], $\sigma-$ alkenyls (59) [134] or $\sigma$-alkynyls (60) [135]. Moreover, reaction of phosphines with $\pi$-alkenes [136] and $\pi$-alkynes (61)-(64) [137-140] have also been reported. It is not possible to explain in depth each reaction, but the variety of resulting products provides an adequate perspective about the synthetic possibilities of this type of reactions.

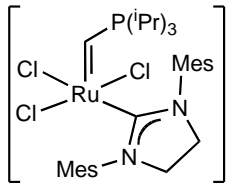

(57)

phosphine + carbyne<smiles>[R]C1=CPPP[P+]1(Cl)Cl</smiles>

$(61)$
phosphine $+\pi$-alkyne $\quad$ phosphine $+\pi$-alkyne

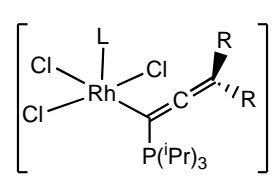

(58) phosphine + allenylidene

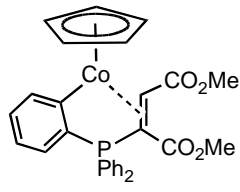

$\begin{array}{cc}(61) & (62) \\ \text { phosphine }+\pi \text {-alkyne } & \text { phosphine }+\pi \text {-alkyne }\end{array}$

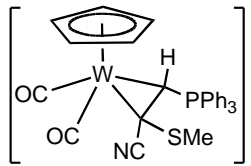

(59)

phosphine $+\sigma$-alkenyl

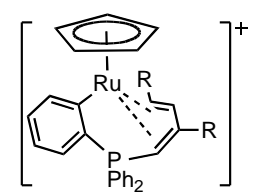

(63)

phosphine $+2 \pi$-alkyne

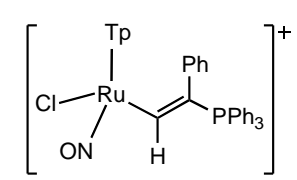

$(60)$

phosphine $+\sigma$-alkynyl<smiles>CCOC(=O)C(=CC1CCCCC1)C(=O)OCC</smiles>

(64)

Scheme 17 Reactivity of nucleophiles (ylides, $\mathbf{P R}_{3}$ ) towards unsaturated substrates

This first section has exposed the most relevant preparative methods in order to obtain coordinated ylides. There are numerous possibilities, the resulting compounds are fascinating and open new doors to future research. Now we will deal with complexes showing particular bonding modes- prepared following one of the reported methods or a slightly different variant- and which exhibit a particular feature.

\section{4}

\section{Complexes with Ylides as Bidentate $\kappa^{1} \mathrm{C}-\kappa^{1} \mathrm{E}$ Ligands}

The $\kappa^{1} \mathrm{C}$ bonding mode includes most of the reported work on ylides. However, modifications of the structure of the ylide could be advantageous, in particular the introduction of additional donor atoms to form chelate ligands. The combination of the pure $\sigma$-donor properties of the ylide with those of the auxiliar donor atom could be used for tuning the steric and electronic properties of ylide complexes. There are reports of usefuls C,P- and C,C-chelates, which will be here detailed. A very good example of this methodology is the recent application of the chiral properties of the ylides to enantioselective homogeneous catalysis. Chiral $\mathrm{Rh}$ complexes (65), prepared by ligand displacement (Scheme 18), has all chirality sources at the phosphine fragment, [141], while the Pd counterparts contains an additional stereogenic center at the ylidic carbon [142]. These Pd complexes are 


\section{Ylide Ligands}

adequate catalysts for enantioselective allylic substitution reactions, achieving ee up to $90 \%$. An improved chiral environment has been obtained in the more rigid six-membered ring of (66), which contains two adjacent stereogenic centers. In this case, the two diastereoisomers can be isolated separately, and both are configurationally stable $[143,144]$. In spite of this, low ee were observed on hydrosilylation or hydrogenations catalyzed by $\mathrm{Rh}(\mathrm{I})$ complexes. Further studies show that the $\mathrm{Rh}-\mathrm{C}$ bond is cleaved in acidic medium, while epimerization occurs in basic medium, these facts being responsible of the low ee values.<smiles>[Y20]C([Z])[Pb]c1ccc2ccccc2c1C1=Cc2cccc3cccc1c23</smiles>

(65)

$M L_{n}=R h(C O D), Z=H$ $\mathrm{ML}_{n}=\mathrm{Pd}(\mathrm{dba}), \mathrm{Z}=\mathrm{CN}, \mathrm{CO}_{2} \mathrm{Et}$

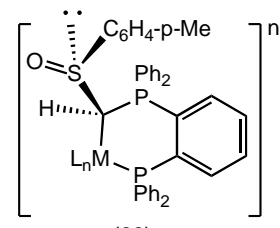

(66)

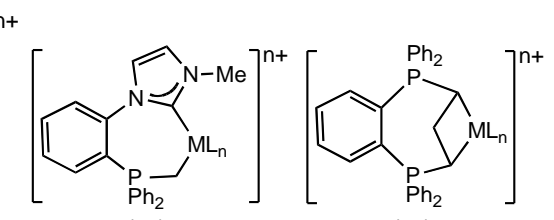

(67)
(68)

\section{Scheme 18 Chiral chelating P,C-ylide and C-ylide,C-carbene complexes}

A different approach to the modulation of steric and electronic properties has been reported using NHC moieties as ancillary ligands. A very rich chemistry has been developed around this topic in the last years [145-148]. Complexes (67) have been prepared by deprotonation of the corresponding phosphonium-imidazolonium salt. The analysis of several $R h^{\mathrm{I}}$ derivatives (67) shows that the ylide behave as a very strong $\sigma$-donor, even more than the NHC ligand, and that $\mathrm{Pd}^{\mathrm{II}}$ complexes are efficient catalysts in allylic substitution reactions $[145,146]$. It is very worthy of note that the synthesis of the related bis-ylide complex (68) (Scheme 18) was not straighforward at all, and that many interesting species were isolated and characterized during its synthesis, finally achieved using cyclic bis-ylides.

Recent research on aminocarbenes has allowed the development of a very fruitful field. The synthesis of relevant complexes (Scheme 19) such as aminobis(ylide) carbene species (69) [147], cyclic C-amino P-ylides (70) (easily transformed into carbenes) [148] and their corresponding complexes (71) [149], and special ylides (72), which also transforms very easily into carbenes by loss of pyridinium group, has been reported. Emphasis has been made on the transformation between ylides and carbenes and on the donor properties of the ylides. From the obtained results the ylides have shown a stronger $\sigma$-donor behaviour compared with the carbenes.

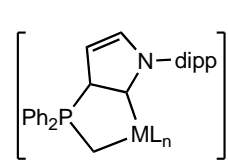

(69)<smiles>[R7]P1(CC)=C(N)C(P)(P)c2cc(C)cc(C)c21</smiles>

(70)<smiles>Cc1cc(C)c2c(c1)C(P)(P)[PH](P)(P)C([18O])C2[NH3+]</smiles>

(71)

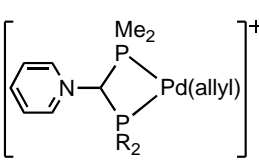

(72)

$M L_{n}=\operatorname{Rh}(\mathrm{CO})_{2}, \operatorname{Pd}\left(\eta^{3}\right.$-allyl)

Scheme 19 Different aminocarbene/ylide complexes 


\section{Ylide Ligands}

Ylides containing aryl substituents are specially prone to undergo activation of $\mathrm{CH}$ bonds when they reacts with electrophilic metal reagents. The outstanding importance of the metal-mediated $\mathrm{CH}$ bond activation as a tool for functionalization of organic substrates is besides all consideration [151]. When several $\mathrm{CH}$ bonds can be activated on the same molecule and on equivalent positions, then a problem of selectivity appears. This is usually overcome by introduction of a directing group, which also coordinates to the metal center. In the case of aromatic systems the metallation is thus directed to the ortho position with respect to the directing group, giving rise to orthometallated complexes. In the case of ylides several studies have been devoted to the preparation of this type of compounds, as presented in Schemes 20-23. It seems more or less clear that the reaction consists in two different steps, the first one being the coordination of the ylide (the directing group) and the second one the $\mathrm{CH}$ bond activation itself. The first example of these reactions was reported by Burmeister et al [152], correcting a previous work [31]. The reaction of $\mathrm{PtCl}_{2}$ with $\mathrm{Ph}_{3} \mathrm{P}=\mathrm{CHC}(\mathrm{O}) \mathrm{Me}$ was expected to give the coordination product (1) [31], but the actual reaction product is the orthoplatinated (73) [152]. Further work of Vicente et al in Pd complexes allowed to prepare either (1) or (73) as a function of the reaction conditions [153].

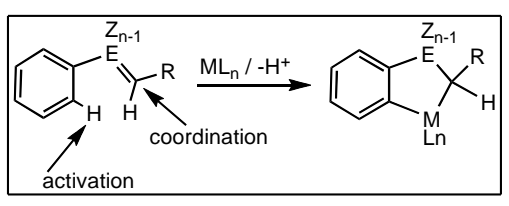

Scheme 20 Orthometallation of ylides; principles and first examples

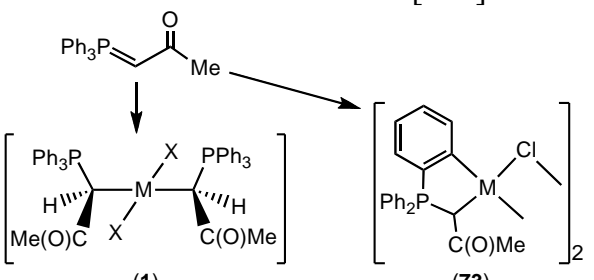

(73)

Most of the chemistry performed on orthometallated ylides has been carried out with $\mathrm{Pd}$ and $\mathrm{Pt}$ as metal centers. Few examples dealing with other metals (Co, $\mathrm{Ru}$ and Os mainly, see 62 and 63) have been reported. Complex (74) has been prepared by reaction of a $\mathrm{Ru}$-vinylidene with $\mathrm{PPh}_{3}$ [154] while $\mathrm{Os}^{\mathrm{IV}}$ derivative (75) has been obtained after treatment of the methylimido complex with $\mathrm{PPh}_{3}$ [155]. Orthoruthenated indenyl complexes [156] have been synthesized by reaction of the halomethyl precursors with $\mathrm{PPh}_{3}$, and the oxidative addition of the ylide $\mathrm{Ph}_{3} \mathrm{P}=\mathrm{CHC}(\mathrm{O}) \mathrm{H}$ to clusters of $\mathrm{Ru}^{0}$ and/or $\mathrm{Os}^{0}$ also allows the synthesis of orthometallated complexes $[157,158]$. In spite of the synthesis of very interesting compounds, the latter are not general preparative methods.

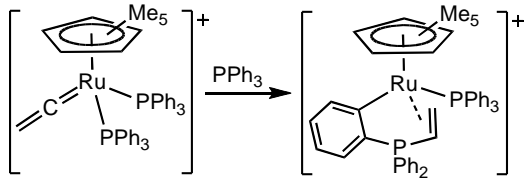

(74)

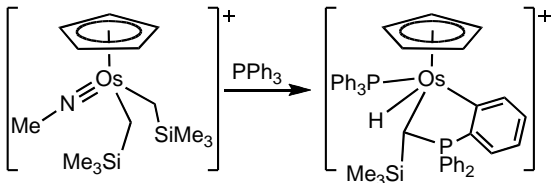

(75)

Scheme 21 Orthometallation of ylides; ruthenium and osmium examples 


\section{Ylide Ligands}

As we have stated in the preceding paragraph, the main part of the orthometallated derivatives are $\mathrm{Pd}^{\mathrm{II}}$ and $\mathrm{Pt}^{\mathrm{II}}$ complexes. Compounds structurally similar to (73) have been prepared by different authors [159-161]. In the reported examples, the $\mathrm{CH}$ bond activation step has been promoted by thermal activation. This is also the case of the rearrangement of bis-ylide complexes (76), which evolve to orthopalladated (77) after heating in NCMe for $8 \mathrm{~h}$ (Scheme 22). The chemistry of bis-ylides is more rich than anticipated, as we will see in section 3, and allows additional ways to promote the $\mathrm{CH}$ bond activation, such as the addition of bulky ligands (regardless the nature of the donor atom) or even an spontaneous reaction can occur [162]. The cleavage of the chloride bridging system in (76) allows the obtention of (78) in very mild conditions only when $\mathrm{L}$ is a bulky ligand $\left(\mathrm{PPh}_{3}\right)$.<smiles>CN(C)CCc1ccccc1P(C)(Cl)(Cl)C(Pc1ccccc1)C(=O)Cc1ccccc1</smiles>

(77)

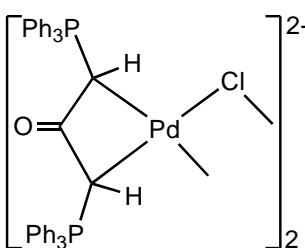

(76)

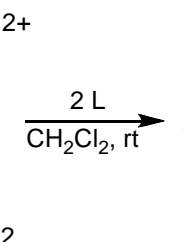<smiles>[3H][P+]1(Cl)c2ccccc2PC1C(=O)CPc1ccccc1</smiles>

(78)

Scheme 22 Different ways to promote orthometallation on Pd(bis-ylide) complexes

The thermal promotion of the $\mathrm{CH}$ bond activation is largely the best preparative method if $\mathrm{Pt}^{\mathrm{II}}$ derivatives are the target. Several complexes have been reported starting not only from ylides, but also from phosphonium salts, in very harsh conditions (refluxing 2-methoxyethanol). Scheme 23 resumes some recent contributions. While the synthesis of complexes (79) is conceptually very similar to that of (77) (an electrophilic substitution in aromatic ring followed by an intramolecular acid-base reaction) [163], the change of the carbonyl group by the olefin group promotes a 1,3-sigmatropic shift after metallation in (80), and the subsequent transformation of an allyl-phosphonium salt into a platinated vinyl phosphonium salt. The synthesis of (81) [164] represents a quite complicated process since it involves three $\mathrm{CH}$ and one $\mathrm{CP}$ bond activations, and one $\mathrm{CC}$ bond coupling. The structural diversity throughout all these situations is evident.

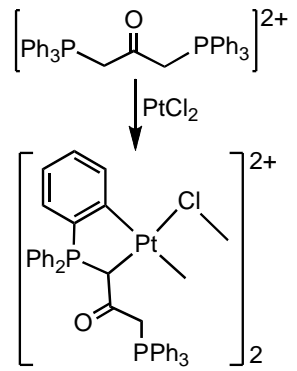

(79)

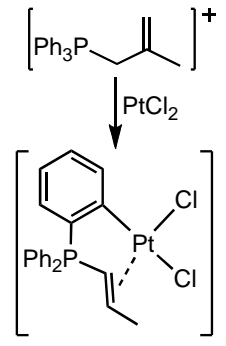

(80)

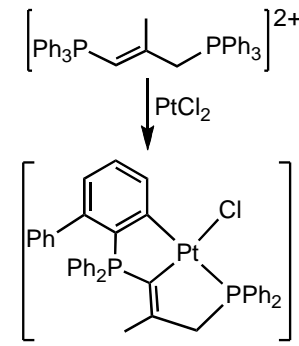

(81)

Scheme 23 Different orthoplatination reactions from ylide and phosphonium salts 


\section{Ylide Ligands}

Additional types of $\kappa^{1} \mathrm{C}-\kappa^{1} \mathrm{E}$ chelating ylide complexes merit to be mentioned here, in addition to the species already presented, and some of them are shown in Scheme 24. The first one is formed by ylides containing a pyridine functionality as substituent of the ylidic carbon. This type of ligands has allowed the synthesis of many "loose clusters" $(82)$ of $\mathrm{Cu}^{\mathrm{I}}, \mathrm{Ag}^{\mathrm{I}}$ and $\mathrm{Au}^{\mathrm{I}}$ which show weak metal $\left(\mathrm{d}^{10}\right)$ metal $\left(\mathrm{d}^{10}\right)$ interactions. These facts have prompted the definition of a new phenomen (numismophilicity) to account these weak interactions, singularity shared by the three coinage metals [165]. Nitrogen and sulfur keto-stabilized ylides have been reacted towards $\mathrm{Pt}^{\mathrm{II}}$ and $\mathrm{W}^{0}$ derivatives and, while $\mathrm{C}$-bonding is produced in the platinum case $(\mathbf{8 3})$, $\mathrm{O}$-bonding is observed for the tungsten derivatives (84) [166-169].

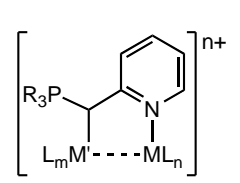

(82)

$\mathrm{ML}_{\mathrm{n}}, \mathrm{ML}_{\mathrm{m}}^{\prime}=\mathrm{AuPPh}_{3}$ $\mathrm{AuCl}, \mathrm{Ag}$

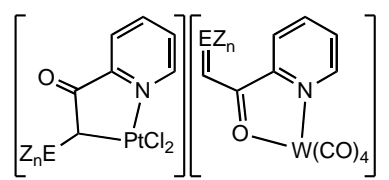

(83)

$$
\mathrm{EZ}_{\mathrm{n}}=\mathrm{SMe}_{2}, \mathrm{NC}_{5} \mathrm{H}_{5}
$$

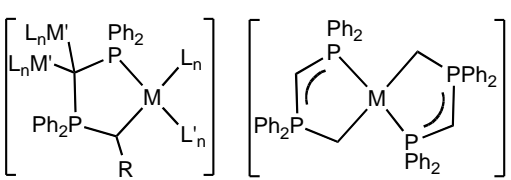

(85)

$\mathrm{M}=\mathrm{Pd}, \mathrm{Pt} ; \mathrm{L}_{\mathrm{n}}=\mathrm{Cl}, \mathrm{py}, \mathrm{C}_{6} \mathrm{~F}_{5}$

$M=A u, L_{n}=C_{6} F_{5} ; M^{\prime} L_{n}=A_{u} C_{6} F_{5}$,

$\mathrm{AuCl}, \mathrm{AgPPh}_{3}$

Scheme 24 Some possibilities of bidentate ylides and observed bonding modes

Complexes (85) with ylides derived from bis-phosphines, dppm or dppe, have been more extensively developed than previous examples. First contributions start to appear in middle seventies using stabilized derivatives [170] and several authors have contributed throughout the years to this field [171,172]. The methylenic protons between the two phosphorus atoms of these chelating ligands, even coordinated, are acidic and, therefore, can be easily removed and replaced by other electrophilic substrates. Using this concept, Laguna et al have prepared a large series of mono-, di- and trinuclear complexes of general structure $(\mathbf{8 5})$, mixing a central square-planar $\mathrm{Au}^{\mathrm{III}}$ center and peripheric $\mathrm{Au}^{\mathrm{I}}$ or $\mathrm{Ag}^{\mathrm{I}}$ metal centers [173-175]. In contrast with the numerous examples reported with stabilized ylides, very few representatives of non-stabilized ylides (86), shown in Scheme 24, appear in the literature [176-178]. Clearly, the combination of the strong $\sigma$-donating ability of the ylidic $\mathrm{C} \alpha$ atom with the properties (steric and/or electronic) of the ancillary heteroatoms in chelating ylides, offers a huge variey of structural motifs. These can be fine tuned in order to obtain the desired results. Applications of these ylide complexes to catalytic processes or functionalization of molecules are of broad interest and show promising results. However, these systems are not yet completely explored and merit further development.

\section{5}

\section{Complexes with Ylides as Bidentate $\kappa^{2} \mathrm{C}, \mathrm{C}$ Ligands}

The last group of ylide complexes in this personal classification is devoted to bisylides, due to their particular bonding properties. Some main types of bis-ylides 


\section{Ylide Ligands}

can be easily identified, and they are anionic or neutral species behaving as chelating or bridging ligands. These bonding modes correspond to classes V, VI and VII in Scheme 3. On the other hand, some of the different strategies to build a bis-ylide are presented in Scheme 25. When the bis-ylide contains only one heteroatom bonded to the two ylidic carbons, an anionic species is obtained (Scheme 25, left), while neutral compounds are the consequence of the presence of one heteroatom for each ylidic C $\alpha$ atom. In this second possibility (Scheme 25, right), three substructures can be envisaged: both terminal ylidic carbons, both terminal heteroatoms ("onium groups") and a mixed arrangement. The synthesis of both-terminal bis-ylides (for instance, from diphosphines) is quite difficult, as we have seen in the synthesis of (67) and (68), due to intramolecular rearrangements. This problem is circumvented using cyclic bis-ylides. The bisterminal "onium group" is the most frequent arrangement, since it starts from readily available dihalide precursors. The mixed situation is barely represented.

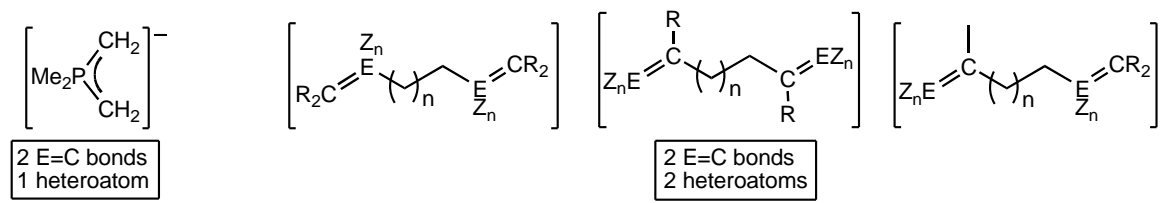

Scheme 25 Different strategies to build bis-ylide skeletons

The use of anionic bis-ylides acting as chelating ligands is also scarcely developed. Different synthetic approximations can be found for synthesis of complexes type $\mathrm{V}$, and the resulting complexes are shown in Scheme 26. Lin et al have reported an extensive work on complexes (87) containing sulfur bis-ylides. The synthesis is carried out in aqueous media using phase transfer catalysis, starting from the sulfonium salt $\left[\mathrm{Me}_{3} \mathrm{SO}\right] \mathrm{X}$ and the metal salt in presence of $\mathrm{NaOH}$. This method tolerates the presence of a wide variety of functional groups and/or ancillary ligands $L_{n}[179-183]$. It is very worthy of note that both the ylide ligands and the resulting complexes are water soluble. Therefore they can be considered very promising candidates as palladium sources in $\mathrm{Pd}$-catalysed processes occurring in water. Phosphorus bis-ylides bonded to $\mathrm{Co}^{\mathrm{III}}(\mathbf{8 8})$ and $\mathrm{Ni}^{\mathrm{II}}$ (89) have been prepared [184] by reaction of the free ylide with the corresponding precursors [for instance, $\mathrm{Ni}(\mathrm{CO})_{4}$ in the case of $(\mathbf{8 9})$ ]. However, $\mathrm{Pd}^{\mathrm{II}}$ complexes (90) were obtained by different methods as a function of the substituents. In the case of the unsubstituted compound $(\mathrm{E}=\mathrm{H})$ the bis(methanide) $\left[\mathrm{Pd}\left(\mathrm{Ph}_{2} \mathrm{PCHPPh}_{2}\right)_{2}\right]$ reacts with the free ylide $\mathrm{Me}_{3} \mathrm{P}=\mathrm{CH}_{2}$ [185], acting the deprotonated dppm as internal base and giving the mixed ylide-methanide (90), while the substituted complex $\left(\mathrm{E}=\mathrm{CO}_{2} \mathrm{Me}\right)$ is prepared by transmetallation from the corresponding $\mathrm{Ag}^{\mathrm{I}}$ compound [186]. Only in the case of the synthesis of (91) the nucleophilic lithium derivative $\mathrm{Li}\left[\mathrm{R}_{2} \mathrm{P}\left(\mathrm{CH}_{2}\right)_{2}\right]$ is needed [187]. 


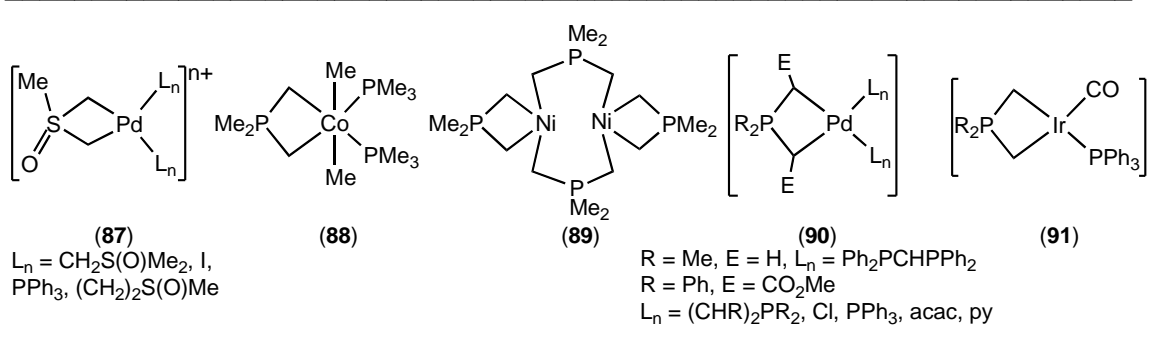

Scheme 26 CC-chelating anionic bisylides in different transition metals

Examples of cyclic bis-ylide complexes are shown in Scheme 27. The neutral double ylide is easily prepared from dppm and 1,2- $\left(\mathrm{BrCH}_{2}\right)_{2} \mathrm{C}_{6} \mathrm{H}_{4}$ and subsequent deprotonation with $\mathrm{KH}$ [188]. It is noteworthy that the second deprotonation is produced at the methylene group between the two $\mathrm{P}$ atoms. This unsymmetrical species reacts with $\mathrm{ZnMe}_{2}$ giving (92), in which the central carbon atom is bonded to the $\mathrm{Zn}$ metal center. In addition, this unsymmetrical species can be further deprotonated at the remaining methylene group to give a symmetrical triple-ylide anion which coordinates to $\mathrm{Co}^{\mathrm{II}}, \mathrm{Fe}^{\mathrm{II}}$ or $\mathrm{Mn}^{\mathrm{II}}$ complexes giving (93) [189] as shown in Scheme 27. Note the different bonding mode of the neutral $(\mathbf{9 2})$ and the anionic (93) species. Stabilized cyclic bis-ylides have been reported for $\mathrm{Pd}^{\mathrm{II}}$ $[190,191]$. Complexes containing the anionic ligand $\left[\mathrm{H}_{2} \mathrm{C}=\mathrm{PPh}_{2} \mathrm{CHPPh}_{2}=\mathrm{CH}_{2}\right]^{-}$ bonded to $\mathrm{Ni}^{\mathrm{II}}, \mathrm{Pd}^{\mathrm{II}}, \mathrm{Pt}^{\mathrm{II}}$ or $\mathrm{Au}^{\mathrm{III}}$ through the two terminal ylidic carbons (see Scheme 25) have been prepared [192], but starting from the carbodiphosphorane $\mathrm{Me}_{3} \mathrm{P}=\mathrm{C}=\mathrm{PMe}_{3}$ and the corresponding metallic halide.

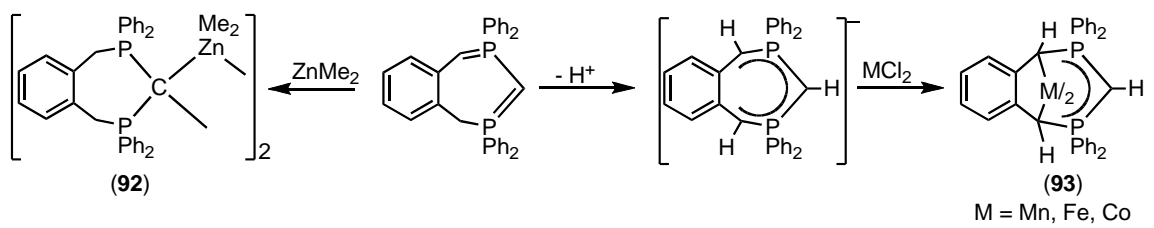

Scheme 27 Cyclic bisylides in different transition metals

Neutral bis-ylides with both terminal "onium groups" have been prepared with different heteroatoms and stabilizing groups, and have been coordinated to different metals (Schemes 28, 29). Bridging (94) [193] and chelating (76) [194201] bonding modes have been reported. The most employed system is $\left[\mathrm{Ph}_{3} \mathrm{P}=\mathrm{CHC}(\mathrm{O}) \mathrm{CH}=\mathrm{PPh}_{3}\right]$, a keto-stabilized phosphorus bis-ylide. In contrast with the stabilized ylides $\mathrm{R}_{3} \mathrm{P}=\mathrm{CHC}(\mathrm{O}) \mathrm{R}$ ' (usually air- and moisture-stable for months), this bis-ylide is quite unstable, and different synthetic alternatives to the simple ligand displacement have been developed. Complex (76) is obtained by reaction of the phosphonium salt with $\left[\mathrm{Pd}(\mathrm{OAc})_{2}\right]$, while gold complex $(\mathbf{9 4})$ is synthesized by transmetallation from the corresponding $\mathrm{Ag}^{\mathrm{I}}$ complex, prepared in turn from the bis-phosphonium through a transylidation process [193]. 


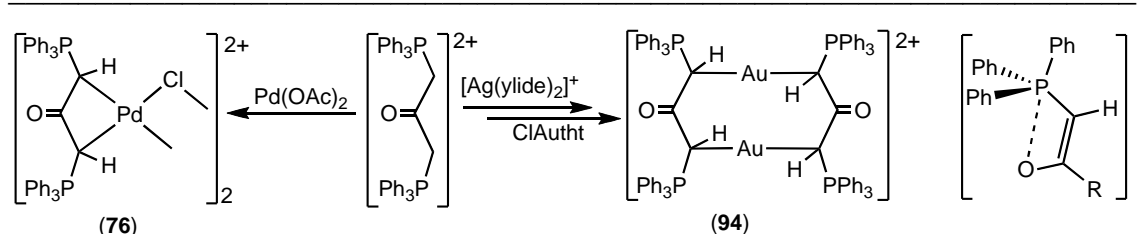

Scheme 28 Different bonding modes of $\left[\mathrm{Ph}_{3} \mathrm{PCHC}(\mathrm{O}) \mathrm{CHPPh}_{3}\right]$

The coordination of this ligand, either to Au [193] or to Pd or Pt metals [163,194], in chelating or bridging modes, reveals a extremely important fact. In spite of the presence of two prochiral centers in the starting free ligand, the bonding of the bis-ylide occurs with complete diastereoselectivity and only one of the two possible diastereoisomers -the meso form, with configurations $R S / S R-$ is obtained. This empirical observation was related with structural features: the cationic phosphonium groups are always in cisoid form with respect to the carbonyl $\mathrm{C}=\mathrm{O}$ bond, the phosphorus - oxygen intramolecular non-bonding distance is always shorter than the sum of the van der Waals radii, and the dihedral angle $\mathrm{P}-\mathrm{C} \alpha-\mathrm{C}=\mathrm{O}$ is always close to zero. All these experimental evidences, already noted by other authors [195], points out to the existence of conformational preferences in stabilized P ylides. These conformational preferences were studied by DFT methods [196] in model compounds, which showed that the cisoid form is energitically more stable than the transoid form (about $10 \mathrm{kcal} \mathrm{mol}^{-1}$ ), that the interconversion cisoid-transoid needs more than $20 \mathrm{kcal} \mathrm{mol}^{-1}$ to be reached, and that the presence of one oxygen $(\mathrm{C}=\mathrm{O}$ group $)$ or one strongly electronegative atom is critical for the establishment of these preferences. The topological study (AIM) of the electron density [196] showed the existence of bond critical points between the positively charged $\mathrm{P}$ atom and the negatively charged $\mathrm{O}$ atom, and also the presence of ring critical points involving the $\mathrm{P}-\mathrm{C} \alpha-\mathrm{C}=\mathrm{O}$ ring. Therefore, there is a true interaction between $\mathrm{P}$ and $\mathrm{O}$ atoms (Scheme 28, right), this interaction is of electrostatic nature and is the final responsible of the conformational preferences. These preferences are transferred to the metallic complexes, since it has been shown that the energy difference between the two metallic diastereisomers mainly comes from the difference between geometric isomers (cisoid - transoid) in the free ligands [197].

Interestingly, the existence of conformational preferences on bis-ylides is not limited to phosphorus ylides, and recent work has extended this study to nitrogen, arsenic and sulfur ylides [198-201]. Complexes derived from pyridinium (95) [198] or imidazolium [199] show strictly the same conformational preferences, since only the meso form is obtained (Scheme 29). However, the phenomenon which originates the conformational preferences in these cases are not the predictable nitrogen-oxygen electrostatic interactions, but the presence of hydrogen bonds between the ortho pyridinium (or the imidazolium) protons and the carbonyl oxygen. The hydrogen bonds have also been studied in model systems and characterized using AIM tools [198]. Moreover, the presence of two different "onium groups" in the same molecule has been studied in complexes 
(96), showing that the two sources of conformational preferences are not mutually exclusive and, once again, obtaining this type of complexes with total diastereoselectivity [200]. A recent report describes a similar situation in sulfur ylides (97) without characterization of the source of preferences [201]. Complex (98) does not have a carbonyl group and, according with previous DFT studies, must not show conformational preferences. In fact, complex (98) has been obtained as the dl-pair, but in a similar $\mathrm{Zr}^{\mathrm{IV}}$ complex the ylide bonds as the meso form showing that the two forms are isoenergetic [202].

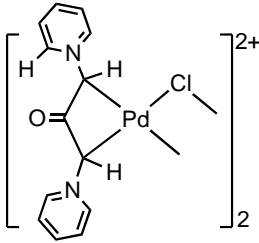

(95)

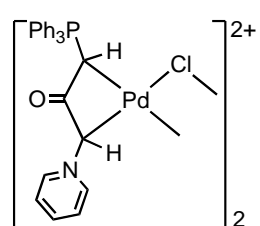

(96)

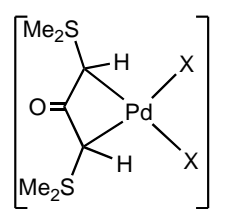

(97)

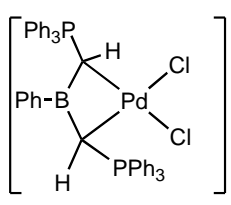

(98)

Scheme 29 Conformational preferences on $\mathrm{Pd}$ complexes of $\left[\mathrm{Ph}_{3} \mathrm{PCHC}(\mathrm{O}) \mathrm{CHPPh}_{3}\right]$

The anionic bis-ylide compounds $\left[\mathrm{R}_{2} \mathrm{P}\left(\mathrm{CH}_{2}\right)_{2}\right]^{-}$bonded as bridging ligands (mode VI) have been extensively studied in complexes of coinage metals, mainly in gold derivatives. Several reasons can be given to this interest, but the most evident is the close proximity of the gold centers in these derivatives, a structural arrangement of exceptional stability provided by the bis-ylide ligands. Moreover, this close proximity favors redox processes in which metal - metal bonds can be formed and cleaved, these facts resulting in a rich and fruitful reactivity.

The bis-ylide ligands $\left[\mathrm{R}_{2} \mathrm{P}\left(\mathrm{CH}_{2}\right)_{2}\right]^{-}$can be easily prepared by treatment of the phosphonium salts $\left[\mathrm{R}_{2} \mathrm{PMe}_{2}\right]^{+}(\mathrm{R}=\mathrm{Me}, \mathrm{Ph})$ with strong deprotonating reagents such as lithium derivatives, $\mathrm{NaNH}_{2}$ or non stabilized ylides $\mathrm{R}_{3} \mathrm{P}=\mathrm{CH}_{2}$. However, $\mathrm{Au}^{\mathrm{I}}, \mathrm{Ag}^{\mathrm{I}}$ and $\mathrm{Cu}^{\mathrm{I}}$ complexes $(99)$ were prepared by reaction of $\mathrm{ClMPMe}_{3}(\mathrm{M}=$ $\mathrm{Ag}, \mathrm{Au}$ ) or $\mathrm{CuCl}$ with excess of $\mathrm{R}_{3} \mathrm{P}=\mathrm{CH}_{2}$ [203,204] (Scheme 30).<smiles>[M]CPCC[R7]P</smiles>

(99)

$\mathrm{M}=\mathrm{Cu}, \mathrm{Ag}, \mathrm{Au}$ $\mathrm{R}=\mathrm{Me}, \mathrm{Ph}$<smiles>[X]C1CPCCC1CPC</smiles>

(99)<smiles>[Y]C12CPC[N+]1(CP)CPC2</smiles>

(100)

$\mathrm{X}=\mathrm{Cl}, \mathrm{Br}$, I

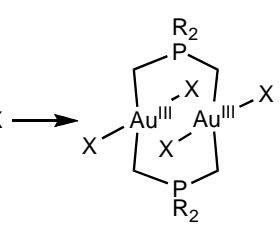

(101)

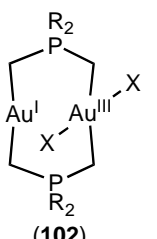

(102)

$\mathrm{X}=\mathrm{Cl}, \mathrm{Br}$

Scheme 30 Dinuclear complexes of coinage metals with the bis-ylide $\left[R_{2} P\left(C_{2}\right)_{2}\right]$

Dimers (99), containing the $\left[\mathrm{Au}^{\mathrm{I}} \mathrm{Au} \mathrm{u}^{\mathrm{I}}\right]$ moiety, undergo two stepwise oxidative additions of halogens $X_{2}$ to give the corresponding $\left[\mathrm{Au}^{\mathrm{II}}-\mathrm{Au}^{\mathrm{II}}\right]$ (100) and $\left[\mathrm{Au}^{\mathrm{III}} \mathrm{Au}^{\mathrm{III}}\right]$ (101) derivatives. The gold-gold intramolecular separation decreases notably from (99) [about $3.0 \AA$ ] to (100) [about $2.6 \AA$ ], in keeping with the 


\section{Ylide Ligands}

presence of a metal-metal bond in the latter, and further increases in (101) [about $3.1 \AA]$ according with the cleavage of the gold-gold bond [206]. Complexes (101) are shown in Scheme 30 as trans-trans, but they could also be obtained in other isomeric forms [206]. Although no formal gold-gold bonds are present in (99) or (101), short metal-metal separations are found (numismophilicity) and, in the case of (101), very unusual structures have been obtained [207]. The oxidative additions to (99) always occurs in the same way, giving complexes (100), which are very stable. Complexes (100) can also be obtained by comproportionation of (99) and (101). However, the $2 \mathrm{e}^{-}$oxidation of a single center in dimer (99) to give the mixed derivative $\left[\mathrm{Au}^{\mathrm{I}} \mathrm{Au}^{\mathrm{III}}\right](\mathbf{1 0 2})$ is not possible at all but, curiously, the $2 \mathrm{e}^{-}$ reduction of (101) (for instance, with $\mathrm{AgCN}$ ) affords (102) in a clean way [208]. Complexes (102) can also be obtained by disproportionation of (100), induced by strong $\sigma$-donors as lithium derivatives $[205,209,210]$ or $\mathrm{R}_{3} \mathrm{P}=\mathrm{CH}_{2}$ [211]. The high trans influence of these ligands seems to destabilize the $\mathrm{Au}^{\text {II }}-\mathrm{Au}^{\text {II }}$ bond and promotes the disproportionation. In fact, a recent work [210] has shown how complexes (100) and (102) containig acetylide ligands can be related by processes of comproportionation and disproportionation. DFT studies of model complexes containing $\left[\mathrm{Au}^{\mathrm{I}} \mathrm{Au}^{\mathrm{I}}\right],\left[\mathrm{Au}^{\mathrm{II}}-\mathrm{Au}^{\mathrm{II}}\right],\left[\mathrm{Au}^{\mathrm{III}} \mathrm{Au}^{\mathrm{III}}\right]$ and $\left[\mathrm{Au}^{\mathrm{I}} \mathrm{Au}^{\mathrm{III}}\right]$ metallic cores have been very recently published [212].

The stabilized versions of (99)-(101) have been easily obtained from the silver derivative (103), shown in Scheme 31 [213]. Treatment of (103) with ClAu(tht) gives (104), which can be oxidized to give the dinuclear complexes (105) and (106) [214]. Interestingly, treatment of (103) with $\mathrm{Pd}^{\mathrm{II}}$ precursors gives complexes in which the bis-ylide is always behaving as a chelate [215].<smiles>O=C(O)C1NC(C(=O)O)C(P(=O)(O)c2ccccc2)C(C(=O)OCc2ccccc2)OC1=O</smiles>
(103)

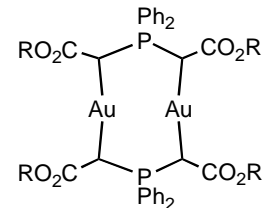

(104)

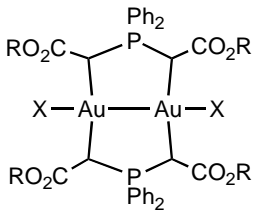

(105)

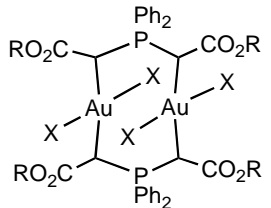

(106)

Scheme 31 Dinuclear complexes with the stabilized bis-ylide $\left[\mathrm{R}_{2} \mathrm{P}\left(\mathrm{CHCO}_{2} \mathrm{R}\right)_{2}\right]$

Due to the facility of the $\left[\mathrm{Au}^{\mathrm{I}} \mathrm{Au} \mathrm{u}^{\mathrm{I}}\right]$ core to undergo oxidative additions, many other substrates have been used. Asymmetric $\left[\mathrm{Au}^{\mathrm{II}}-\mathrm{Au}^{\mathrm{II}}\right]$ complexes $(107)$ have been obtained by oxidative addition of a large variety of alkyl halides RX, as summarized in Scheme 32. Amongst them we have to mention MeI [205,216], EtI [217], $\mathrm{Me}_{3} \mathrm{SiCH}_{2} \mathrm{I}, \mathrm{PhCH}_{2} \mathrm{Br}$ [218], $\mathrm{CCl}_{4}$ [219] or $\mathrm{NCCH}_{2} \mathrm{Br}$ [220]. In some cases [218], the addition of the alkyl halide is reversible. In this respect, the presence of a strongly electron-withdrawing group helps to stabilize the dimer $\left[\mathrm{Au}^{\mathrm{II}}-\mathrm{Au}^{\mathrm{II}}\right]$. The dimers (107) with a nitro ligand at both sides of the $\mathrm{Au}-\mathrm{Au}$ bond have been prepared by oxidative addition of $\mathrm{MeNO}_{2}$ to (99) [221], while those having $\mathrm{CN}$ ligands [222] have been obtained by treatment of (99) with $\mathrm{Hg}(\mathrm{CN})_{2}$. 


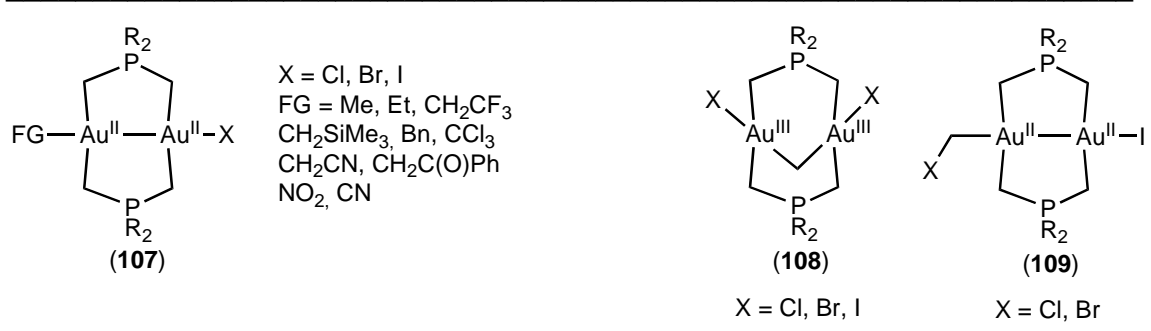

Scheme 32 Asymmetric dinuclear complexes with the ligand $\left[\mathrm{R}_{2} \mathrm{P}\left(\mathrm{CH}_{2}\right)_{2}\right]$

Dihalomethylenes $\mathrm{CH}_{2} \mathrm{X}_{2}$, and related species, also add oxidatively to (99), but the final products are quite different from those already presented. In general, the reaction of (99) with $\mathrm{CH}_{2} \mathrm{X}_{2}$ affords complexes (108), in which both $\mathrm{C}-\mathrm{X}$ bonds add to the gold centers [223]. Complexes (108) show both gold centers in $(+\mathrm{III})$ oxidation state, and are very stable. A proof of this stability is the lack of reactivity of the methylene bridge toward different reagents. A synthetic alternative for $(\mathbf{1 0 8})$ is the reaction of $(\mathbf{1 0 0})$ with $\mathrm{CH}_{2} \mathrm{~N}_{2}$ [224], or other unexpected sources of CHR groups [225]. Soon after the first synthesis of (108) an intermediate (109), containing an haloalkyl ligand, was isolated and characterized [224]. The isolation of (109) allowed the proposal of a reaction mechanism based on carbene species [226]. The reactivity of (108) has been studied in some depth [227].

Each species $(\mathbf{9 9}),(\mathbf{1 0 0}),(\mathbf{1 0 1}),(\mathbf{1 0 2})$ or $(\mathbf{1 0 8})$ has been subjected to a wide variety of substitution processes of the ylide ligand by other anionic ligands, or of the $\mathrm{X}$ ligand by another anionic or neutral L ligands, acting as monodentate, chelate or bridge. This results in a plethora of complexes with very diverse structural features, whose complete description falls away the object of this chapter. However, there are some noteworthy processes which merit to be mentioned here.

The first one describes the solvent-promoted $\left(\mathrm{MeNO}_{2}\right.$, acetone) isomerization of (100) into a $\left[\mathrm{Au}^{\mathrm{I}} \mathrm{Au}^{\mathrm{III}}\right]$ mixed complex (110) (Scheme 33) [228], related with the synthesis of (102). The critical step in this process is the cleavage of the dimer. Here the strong $\sigma$-donor is not necessary, since a weakly donor solvent promotes the reaction, but it should be noted that the final structure contains one of the bisylides acting as a chelating ligand. This cleavage seems to be involved in other relevant reactions. For instance, the dimer $\left[\mathrm{Au}\left(\mathrm{CH}_{2}\right)_{2} \mathrm{PPhMe}\right]_{2}$, type (99), is obtained in trans form, that is, with the two Ph groups in opposites sides of the molecular plane. The addition of Lewis acids to (99) (even the reaction solvent) promotes its isomerization to the cis form, through species (111) [229]. The addition of a very strong Lewis acid (hydrogen halides) results in the cleavage of (99) and protonation of the bis-ylide, giving C-bonded ylides (6) [230], or in the formation of dimers (112) if protonation is performed in presence of chelating ligands LL [231]. Dimer (99) can also be cleaved by metallic electrophiles. In this case, a further transylidation from (99) to the incoming metallic electrophile is observed, giving trinuclear species (113) [232]. 


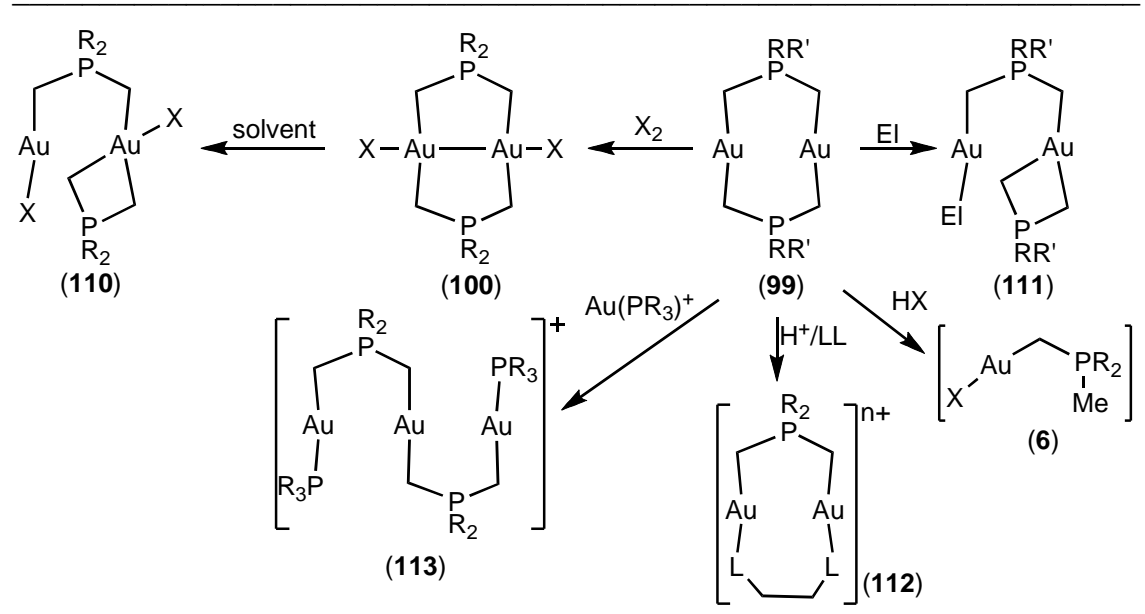

Scheme 33 Representative reactivity of complexes with the ligand $\left[R_{2} P\left(C_{2}\right)_{2}\right]$

The reactivity of the electron rich dimeric gold (I) derivative (99) towards electrophiles (metallic or not) seems to begin by direct attack of the electrophile to the gold center, forming a direct $\mathrm{Au}^{\mathrm{I}}-\mathrm{El}$ bond. This concept has been used to build polynuclear gold complexes in various oxidation states, starting from (99) and with different reagents. Some outstanding results are shown in Scheme 34.

The reaction of $(\mathbf{9 9})$ with $\left(\mathrm{C}_{6} \mathrm{~F}_{5}\right)_{3} \mathrm{AuOEt}_{2}$ produces cleanly trimer (114) through an acid-base Lewis process. However, the assignation of the individual oxidation states for the gold atoms is not evident from the X-ray data [233]. A very different process is observed when (100) is reacted with $\left(\mathrm{C}_{6} \mathrm{~F}_{5}\right)_{3} \mathrm{AuOEt}_{2}$, since the pentanuclear complex (115) is obtained, together with the byproduct $\mathrm{F}_{5} \mathrm{C}_{6}-\mathrm{C}_{6} \mathrm{~F}_{5}$.

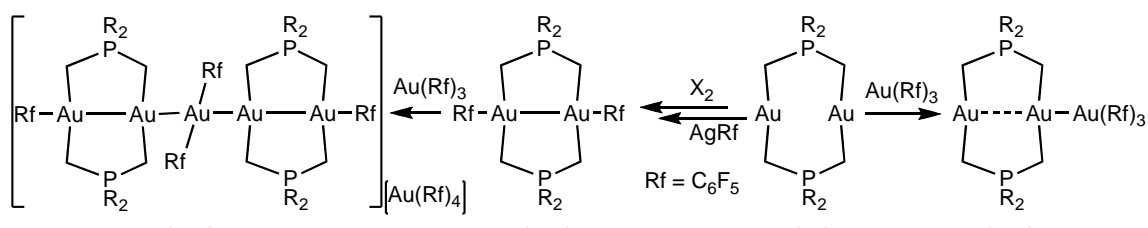

(115)

(100)

(99)

(114)

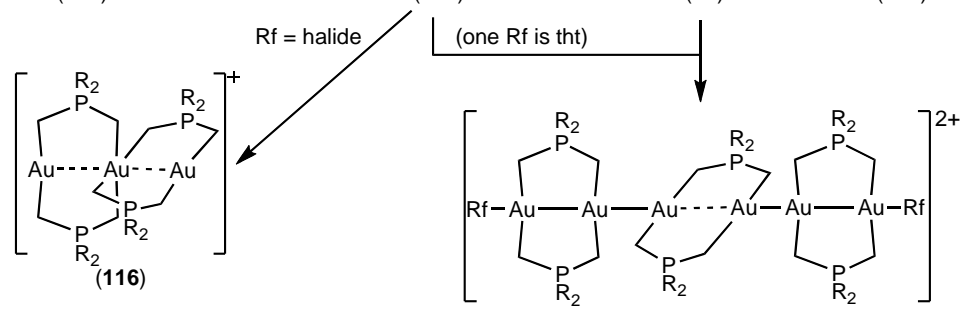

(117)

Scheme 34 Synthesis of polynuclear complexes with the ligand $\left[\mathrm{R}_{2} \mathrm{P}\left(\mathrm{CH}_{2}\right)_{2}\right]$ 


\section{Ylide Ligands}

The assignation of oxidation states in (115) is even less evident than in (114), and it has been proposed as $\left\{\left[\mathrm{Au}^{\mathrm{II}} \mathrm{Au}{ }^{\mathrm{II}}\right]\left[\mathrm{Au}^{\mathrm{I}}\right]\left[\mathrm{Au}^{\mathrm{II}} \mathrm{Au}^{\mathrm{II}}\right]\right\}^{+}$(giving the first $\mathrm{Au}^{\mathrm{I}}$ center in a square-planar environment) or, alternatively, $\left\{\left[\mathrm{Au}^{\mathrm{II}} \mathrm{Au}{ }^{\mathrm{I}}\right]\left[\mathrm{Au}^{\mathrm{III}}\right]\left[\mathrm{Au}^{\mathrm{I}} \mathrm{Au}{ }^{\mathrm{II}}\right]\right\}^{+}$, which is also an unprecedent situation [234]. Complexes (116) are obtained in the disproportionation of (100), induced by strong $\sigma$-donors as $\mathrm{R}_{3} \mathrm{P}=\mathrm{CH}_{2}$ [211], regardless the nature of the halide. In this case there is no doubt about the oxidation state. since a chain $\left[\mathrm{Au}^{\mathrm{I}} \mathrm{Au}{ }^{\mathrm{III}} \mathrm{Au} \mathrm{u}^{\mathrm{I}}\right]$ is clearly identified. Gold(II) dimers (100) behaves as nucleophiles when reacting with the highly electrophilic $\mathrm{Au}(\mathrm{Rf})_{3}$ derivatives, giving (115), but they can also behave as electrophiles towards highly nucleophilic compounds (99). In this respect, (117) is a very good example of this versatility [235].

Finally, a more classical reactivity dealing with simple ligand substitution has been developed. Some notable contributions must be mentioned here as the synthesis of water-soluble $\mathrm{Au}^{\mathrm{II}}$ dimers (118) [236] (Scheme 35) using common procedures [237], the synthesis of very large rings using polysulfide anions [238], the synthesis of heteropolymetallic derivatives (119) [239], the synthesis of complexes with mixed ligands (one ylide and another different anionic ligand) (120) either by ligand substitution in $\mathrm{Au}^{\mathrm{II}}$ precursors or by oxidation of preformed mixed $\mathrm{Au}^{\mathrm{I}}$ complexes [240,241], or the coordination of very elusive ligands, such as the adducts with $\mathrm{SO}_{2}(\mathbf{1 2 1})$ [242].<smiles>CC1CN(C)CPC1C</smiles>

(118)

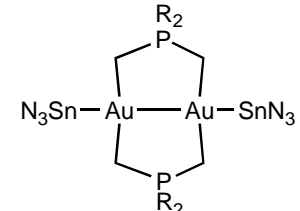

(119)

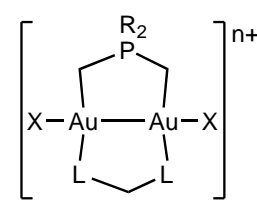

(120)<smiles>O=[N+]([O-])[13C]1CPC[C](S(=O)(=O)[O-])PPC1</smiles>

(121)

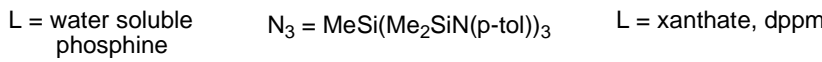

Scheme 35 Miscellaneous reactivity with the anionic bridging ligand $\left[\mathrm{R}_{2} \mathrm{P}\left(\mathrm{CH}_{2}\right)_{2}\right]$

6

\section{Summary}

Complexes of transition metals containing ylides as ligands are known for more than 30 years. During this time, a wide prospect of preparative methods, unusual chemical structures, unexpected reactivity and fascinating applications, even in the industrial field and regardless the transition metal, have been developed. In this chapter a brief summary of the behaviour of ylides towards late transition metals has been presented, covering examples of ylides as monodentate species, as bidentate chelating or bridging ligands, precursors of carbenes, chiral ancillary moieties, hemilabile ligands or stabilizing unusual structures or oxidations states. The importance of the ylides is evident in all areas where they are present, from the merely organic point of view to the organometallic one. Because of that, new 


\section{Ylide Ligands}

applications can be awaited, and additional efforts are necessary to improve and further develop this rich field of the chemistry

\section{Acknowledgements}

The author wishes to thank the Spanish Ministerio de Ciencia y Tecnologia and Ministerio de Educación y Ciencia (Projects CTQ2005-01037 and CTQ200801784) for financial support.

\section{References}

1. Hoffmann RW (2001) Angew Chem Int Ed 40:1411

2. Johnson AW (1993) Ylides and Imines of Phosphorus, John Wiley\&Sons, New York, USA

3. Coyne EJ, Gilheany DG (1995) Comprehensive Organic Functional Group Transformation, Vol 3, Chap 3.13, Pattenden G Vol Ed, Katritzky AR, Meth-Cohn O, Rees CW Eds in Chief, Pergamon Press, Elsevier, Oxford, UK

4. Whittingham WG (1995) Comprehensive Organic Functional Group Transformations, Vol 3, Chap 3.08, Pattenden G Vol Ed, Katritzky AR, Meth-Cohn O, Rees CW Eds in Chief, Pergamon Press, Elsevier, Oxford, UK

5. Kolodiazhnyi OI (1999) Phosphorus Ylides, Wiley-VCH, Weinheim, Germany

6. Clark JS (2002) Nitrogen, Oxygen and Sulfur Ylide Chemistry, Oxford University Press, Oxford, UK

7. Vedejs E, West FG (1986) Chem Rev 86:941

8. Kolodiazhnyi, OI (1996) Tetrahedron 52:1855

9. Padwa A, Hornbuckle SF (1991) Chem Rev 91:263

10. Coldham I, Hufton R (2005) Chem Rev 105: 2765

11. Burton DJ, Yang Z-Y, Qiu W (1996) Chem Rev 96:1641

12. Gilheany DG (1994) Chem Rev 94:1339

13. Li A-H, Dai L-X, Aggarwal VK (1997) Chem Rev 97:2341

14. Sun X-L, Tang Y (2008) Acc Chem Res 41:937

15. Schmidbaur H (1975) Acc Chem Res 8:62

16. Schmidbaur H (1983) Angew Chem Int Ed Engl 22:907

17. Weber L (1983) Angew Chem Int Ed Engl 22:516

18. Laguna A, Laguna M (1990) J Organomet Chem 394:743

19. Cristau, HJ (1994) Chem Rev 94:1299

20. Belluco U, Michelin RA, Mozzon M, Bertani R, Facchin G, Zanotto L, Pandolfo L (1998) J Organomet Chem 557:37

21. Navarro R, Urriolabeitia EP (1999) J Chem Soc Dalton Trans, p 4111

22. Urriolabeitia EP (2008) Dalton Trans, p 5673

23. Bertani R, Casarin M, Pandolfo L (2003) Coord Chem Rev 236:15

24. Chauvin R (2000) Eur J Inorg Chem, p 577

25. Taillefer M, Cristau HJ (2003) Top Curr Chem 229:41

26. Kuhn P, Sémeril D, Matt D, Chetcuti MJ, Lutz P (2007) Dalton Trans, p 515

27. Cantat T, Mézailles N, Auffrant A, Le Floch P (2008) Dalton Trans, p 1957

28. Koezuka H, Matsubayashi G-E, Tanaka T (1974) Inorg Chem 13:443

29. Bravo P, Fronza G, Ticozzi C, Gaudiano G (1974) J Organomet Chem 74:143 


\section{Ylide Ligands}

30. Nishiyama H, Itoh K, Ishii Y (1975) J Organomet Chem 87:129

31. Weleski Jr ET, Silver JL, Jansson MD, Burmeister JL (1975) J Organomet Chem 102:365

32. Bravo P, Fronza G, Ticozzi C (1976) J Organomet Chem 111:361

33. Koezuka H, Matsubayashi G-E, Tanaka T (1976) Inorg Chem 15:417

34. Seno M, Tsuchiya S (1977) J Chem Soc Dalton Trans 751

35. Tewari RS, Awasthi AK (1984) J Organomet Chem 271:403

36. Booth BL, Smith KG (1981) J Organomet Chem 220:219

37. Saito T, Urabe H, Sasaki Y (1980) Transition Met Chem 5:35

38. Saito T (1978) Bull Chem Soc Jpn 51:169

39. Usón R, Laguna A, Laguna M, Usón A, Jones PG, Erdbrügger CF (1987) Organometallics 6:1778

40. Stein J, Fackler Jr JP, Paparizos C, Chen H-W (1981) J Am Chem Soc 103:2192

41. Facchin G, Bertani R, Calligaris M, Nardin G, Mari M (1987) J Chem Soc Dalton Trans 1381

42. Facchin G, Bertani R, Zanotto L, Calligaris M, Nardin G (1989) J Organomet Chem 366:409

43. Albanese JA, Rheingold AL, Burmeister JL (1988) Inorg Chim Acta 150:213

44. Albanese JA, Staley DL, Rheingold AL, Burmeister JL (1989) J Organomet Chem 375:265

45. Barco IC, Falvello LR, Fernández S, Navarro R, Urriolabeitia EP (1998) J Chem Soc Dalton Trans, p 1699

46. Fernández S, García MM, Navarro R, Urriolabeitia EP (1998) J Organomet Chem 561:67

47. Carbó M, Falvello LR, Navarro R, Soler T, Urriolabeitia EP (2004) Eur J Inorg Chem 2338

48. Usón R, Forniés J, Navarro R, Espinet P, Mendívil C (1985) J Organomet Chem 290:125

49. Falvello LR, Fernández S, Navarro R, Urriolabeitia EP (1997) Inorg Chem 36:1136

50. Falvello LR, Fernández S, Navarro R, Pascual I, Urriolabeitia EP (1997) J Chem Soc Dalton Trans, p 763

51. Facchin G, Zanotto L, Bertani R, Canovese L, Uguagliati P (1993) J Chem Soc Dalton Trans, p 2871

52. Belluco U, Michelin RA, Bertani R, Facchin G, Pace G, Zanotto L, Mozzon M, Furlan M Zangrando E (1996) Inorg Chim Acta 252:355

53. Falvello LR, Fernández S, Navarro R, Urriolabeitia EP (1996) Inorg Chem 35:3064

54. Soulivong D, Wieser C, Marcellin M, Matt D, Harriman A, Toupet L (1997) J Chem Soc Dalton Trans, p 2257

55. Pearson RG (1973) Inorg Chem 12:712

56. Falvello LR, Ginés JC, Carbó JJ, Lledós A, Navarro R, Soler T, Urriolabeitia EP (2006) Inorg Chem 45:6803

57. Carbó M, Marín N, Navarro R, Soler T, Urriolabeitia EP (2006) Eur J Inorg Chem, p 4629

58. Laavanya P, Venkatasubramanian U, Panchanatheswaran K, Krause Bauer JA (2001) Chem Commun, p 1660

59. Pandolfo L, Paiaro G, Dragani LK, Maccato C, Bertani R, Facchin G, Zanotto L, Ganis P, Valle G (1996) Organometallics 15:3250

60. Bertani R, Meneghetti F, Pandolfo L, Scarmagnan A, Zanotto L (1999) J Organomet Chem 583:146

61. Bertani R, Casarin M, Ganis P, Maccato C, Pandolfo L, Venzo A, Vittadini A, Zanotto L (2000) Organometallics 19:1373 


\section{Ylide Ligands}

62. Benetollo F, Bertani R, Ganis P, Pandolfo L, Zanotto L (2001) J Organomet Chem 629:201

63. Bertani R, Pandolfo L, Zanotto L (2002) Inorg Chim Acta 330:213

64. Zinner G, Fehlhammer WP (1985) Angew Chem Int Ed Engl 24:979

65. Greco A (1972) J Organomet Chem 43:351

66. Itoh K, Nishiyama H, Ohnishi T, Ishii Y (1974) J Organomet Chem 76:401

67. Starzewski KAO, Dieck HT, Franz KD, Hohmann F (1972) J Organomet Chem 42:C35

68. Hirai M-F, Miyasaka M, Itoh K, Ishii Y (1978) J Organomet Chem 160:25

69. Hirai M-F, Miyasaka M, Itoh K, Ishii Y (1979) J Organomet Chem 165:391

70. Hirai M-F, Miyasaka M, Itoh K, Ishii Y (1979) J Chem Soc, Dalton Trans 1200

71. Spannenberg A, Baumann W, Rosenthal U (2000) Organometallics 19:3991

72. Vicente J, Chicote MT (1999) Coord Chem Rev 193-195:1143

73. Vicente J, Chicote MT, Guerrero R, Jones PG (1996) J Am Chem Soc 118:699

74. Vicente J, Chicote MT, Abrisqueta MD, González-Herrero P, Guerrero R (1998) Gold Bull $31: 126$

75. Vicente J, Chicote MT, Cayuelas JA, Fernández-Baeza J, Jones PG, Sheldrick GM, Espinet P (1985) J Chem Soc, Dalton Trans 1163

76. Vicente J, Chicote MT, Saura-Llamas I, Lagunas MC (1992) J Chem Soc Chem Commun 915

77. Vicente J, Chicote MT, Abrisqueta MD, Alvarez-Falcón MM, Ramírez de Arellano MC, Jones PG (2003) Organometallics 22:4327

78. Schmidbaur H, Gabbaï FP, Schier A, Riede J (1995) Organometallics 14:4969

79. Kermode NJ, Lappert MF, Skelton BW, White AH, Holton J (1982) J Organomet Chem 228:C71

80. Engelbert C, Moss JR, Niven ML, Nassimbeni LR, Reid G (1982) J Organomet Chem 232: C78

81. Hoover JF, Stryker JM (1988) Organometallics 7:2082

82. Werner H, Hofmann L, Paul W, Schubert U (1988) Organometallics 7:1106

83. Toupet L, Weinberger B, Des Abbayes H, Gross U (1984) Acta Crystallogr C40:2056

84. Ferguson G, Li Y, McAlees AJ, McCrindle R, Xiang K (1999) Organometallics 18:2428

85. Leoni P, Marchetti F, Paoletti M (1997) Organometallics 16:2146

86. Rudler H, Audouin M, Parlier A, Martin-Vaca B, Goumont R, Durand-Réville T, Vaiseermann J (1996) J Am Chem Soc 118:12045

87. Zhang C, Guzei IA, Espenson JH (2000) Organometallics 19:5257

88. Djukic JP, Young Jr VG, Woo LK (1994) Organometallics 13:3995

89. Guerchais V, Astruc D, Nunn CM, Cowley AH (1990) Organometallics 9:1036

90. Nakazawa H, Yamaguchi Y, Mizuta T, Ichimura S, Miyoshi K (1995) Organometallics 14:4635

91. Hanks TW, Ekeland RA, Emerson K, Larsen RD, Jennings PW (1987) Organometallics 6:28

92. Casas JM, Diosdado B, Falvello LR, Forniés J, Martín A, Rueda A (2004) Dalton Trans, p 2773

93. Azam KA, Frew AA, Lloyd BR, Manojlovic-Muir L, Muir KW, Puddephatt RJ (1985) Organometallics 4:1400

94. McCrindle R, Ferguson G, Arsenault GJ, McAlees AJ, Ruhl BL, Sneddon DW (1986) Organometallics 5:1171 


\section{Ylide Ligands}

95. Weber L, Lücke E, Boese R (1988) Organometallics 7:978

96. Gandelman M, Rybtchinski B, Ashkenazi N, Gauvin RM, Mistein D (2001) J Am Chem Soc

123:5372

97. Gandelman M, Naing KM, Rybtchinski B, Poverenov E, Ben-David Y, Ashkenazi N, Gauvin RM, Milstein D (2005) J Am Chem Soc 127:15265

98. Falvello LR, Llusar R, Margalejo ME, Navarro R, Urriolabeitia EP (2003) Organometallics 22:1132

99. Vicente J, Chicote MT, MacBeath C, Fernández-Baeza J, Bautista D (1999) Organometallics 18:2677

100. Vicente J, Chicote MT, MacBeath C, Jones PG (2003) Organometallics 22:1843

101. Vicente J, Chicote MT, Fernández-Baeza J, Lahoz FJ, López JA (1991) Inorg Chem 30:3617

102. Vicente J, Chicote MT, Lagunas MC, Jones PG (1995) Inorg Chem 34:5441

103. Vicente J, Chicote MT, Beswick MA, Ramírez de Arellano MC (1996) Inorg Chem 35:6592

104. Facchin G, Campostrani R, Michelin RA (1985) J Organomet Chem 294:C21

105. Michelin RA, Facchin G, Braga D, Sabatino P (1986) Organometallics 5:2265

106. Wagner G, Pakhomova TB, Bokach NA, Frausto da Silva JJR, Vicente J, Pombeiro AJL, Kukushkin VY (2001) Inorg Chem 40:1683

107. Bokach NA, Selivanov SI, Kukushkin VY, Vicente J, Haukka M, Pombeiro AJL (2002) Organometallics 21:3744

108. Bokach NA, Kukushkin VY, Haukka M, Fraústo da Silva JJR, Pombeiro AJL (2003) Inorg

Chem 42:3602

109. Keim W, Kowaldt FH, Goddard R, Krügger C (1978) Angew Chem Int Ed Engl 17:466

110. Kermagoret A, Braunstein P (2008) Dalton Trans, p 822 and references cited therein

111. Lee P-Y, Liang L-C (2008) Inorg Chem 47:749

112. Kuhn P, Sémeril D, Jeunesse C, Matt D, Lutz PJ, Louis R, Neuburger M (2006) Dalton Trans, p 3647

113. Larivée A, Mousseau JJ, Charette AB (2008) J Am Chem Soc 130:52

114. Mousseau JJ, Larivée, Charette AB (2008) Org Lett 10:1641

115. Tonner R, Öxler F, Neumüller B, Petz W, Frenking G (2006) Angew Chem Int Ed 45:8038

116. Pascual S, Asay M, Illa O, Kato T, Bertrand G, Saffon-Merceron N, Branchadell V, Baceiredo A (2007) Angew Chem Int Ed 46:9078

117. Schmidbaur H, Zybill CE, Müller G, Krüger C (1983) Angew Chem Int Ed Engl 22:729

118. Zybill C, Müller G (1987) Organometallics 6:2489

119. Petz W, Weller F, Uddin J, Frenking G (1999) Organometallics 18:619

120. Vicente J, Singhal AR, Jones PG (2002) Organometallics 21:5887 and references therein

121. Schmidbaur H, Gasser O (1976) Angew Chem Int Ed Engl 15:502

122. Petz W, Kutschera C, Neumüller B (2005) Organometallics 24:5038

123. Baldwin JC, Kaska WC (1979) Inorg Chem 18:686

124. Kaska WC, Mitchell DK, Reichelderfer RF, Korte WD (1974) J Am Chem Soc 96:2847

125. Kaska WC, Mitchell DK, Reichelderfer RF (1973) J Organomet Chem 47:391

126. Ramirez F, Levy S (1956) J Org Chem 21:488 


\section{Ylide Ligands}

127. Brownie JH, Baird MC, Schmider H (2007) Organometallics 26:1433 and references therein

128. Nakazawa H, Ueda Y, Nakamura K, Miyoshi K (1997) Organometallics 16:1562

129. Grumbine SK, Mitchell GP, Straus DA, Tilley TD, Rheingold AL (1998) Organometallics 17:5607

130. Li X, Wang A, Wang L, Sun H, Harms K, Sundermeyer J (2007) Organometallics 26:1411

131. Li X, Schopf M, Stephan J, Kipke J, Harms K, Sundermeyer J (2006) Organometallics 25:528

132. van der Eide EF, Romero PE, Piers WE (2008) J Am Chem Soc 130:4485

133. Werner H, Wiedemann R, Laubender M, Windmüller B, Steinert P, Gevert O, Wolf J (2002) J Am Chem Soc 124:6966

134. Kubicki MM, Kergoat R, Scordia H, Gomes de Lima LC, Guerchais JE, L'Haridon P (1988) J Organomet Chem 340:41

135. Nishimura Y, Arikawa Y, Inoue T, Onishi M (2005) Dalton Trans, p 930

136. Du S, Ellis DD, Jellis PA, Kautz JA, Malget JM, Stone FGA (2000) Organometallics 19:1983

137. Allen Jr A, Lin W (1999) Organometallics 18:2922

138. O'Connor JM, Bunker KD (2003) J Organomet Chem 671:1

139. Rüba E, Mereiter K, Schmid R, Kirchner K, Bustelo E, Puerta MC, Valerga P (2002) Organometallics 21:2912

140. Aumann R, Jasper B, Läge M, Krebs B (1994) Chem Ber 127:2475

141. Viau L, Lepetit C, Commenges G, Chauvin R (2001) Organometallics 20:808

142. Ohta T, Sasayama H, Nakajima O, Kurahashi N, Fujii T, Furukawa I (2003) Tetrahedron Asymm 14:537

143. Zurawinski R, Donnadieu B, Mikolajczyk M, Chauvin R (2003) Organometallics 22:4810

144. Zurawinski R, Donnadieu B, Mikolajczyk M, Chauvin R (2004) J Organomet Chem 689:380

145. Canac Y, Lepetit C, Abdalilah M, Duhayon C, Chauvin R (2008) J Am Chem Soc 130:8406

146. Canac Y, Duhayon C, Chauvin R (2007) Angew Chem Int Ed 46:6313

147. Asay M, Donnadieu B, Baceiredo A, Soleilhavoup M, Bertrand G (2008) Inorg Chem 47:3949

148. Canac Y, Conejero S, Soleilhavoup M, Donnadieu B, Bertrand G (2006) J Am Chem Soc 128:459

149. Vignolle J, Donnadieu B, Bourissou D, Soleilhavoup M, Bertrand G (2006) J Am Chem Soc $128: 14810$

150. Vignolle J, Gornitzka H, Maron L, Schoeller WW, Bourissou D, Bertrand (2007) J Am Chem Soc 129:978

151. Dyker G, Handbook of C-H Transformations: Applications in Organic Synthesis (2005) Wiley-VCH, Weinheim, Germany

152. Illingsworth ML, Teagle JA, Burmeister JL, Fultz WC, Rheingold AL (1983) Organometallics 2:1364

153. Vicente J, Chicote MT, Fernández-Baeza J (1989) J Organomet Chem 364:407

154. Onitsuka K, Nishii M, Matsushima Y, Takahashi S (2004) Organometallics 23:5630

155. Koch JL, Shapley PA (1999) Organometallics 18:814 


\section{Ylide Ligands}

156. Park JH, Koh JH, Park J (2001) Organometallics 20:1892

157. Heineke D, Bohle DS, Vahrenkamp H (1993) Chem Ber 126:355

158. Deeming AJ, Nuel D, Powell NI, Whittaker C (1992) J Chem Soc Dalton Trans, p 757

159. Vicente J, Chicote MT, Lagunas MC, Jones PG, Bembenek E (1994) Organometallics 13:1243

160. Facchin G, Zanotto L, Bertani R, Nardin G (1996) Inorg Chim Acta 245:157

161. Aguilar D, Aragüés MA, Bielsa R, Serrano E, Navarro R, Urriolabeitia EP (2007) Organometallics 26:3541

162. Falvello LR, Fernández S, Navarro R, Rueda A, Urriolabeitia EP (1998) Organometallics 18:5887

163. Falvello LR, Fernández S, Larraz C, Llusar R, Navarro R, Urriolabeitia EP (2001) Organometallics 20:1424

164. Gracia C, Marco G, Navarro R, Romero P, Soler T, Urriolabeitia EP (2003) Organometallics 22:4910

165. Vicente J, Chicote MT, Lagunas MC (1993) Inorg Chem 32:3748

166. Matsubayashi G-E, Kondo Y, Tanaka T, Nishigaki S, Nakatsu K (1979) Chem Lett, p 375

167. Matsubayashi G-E, Kawafune I, Tanaka T, Nishigaki S, Nakatsu K (1980) J Organomet Chem 187:113

168. Matsubayashi G-E, Ueyama K, Nakatsu K (1982) J Organomet Chem 240:103

169. Kawafune I, Matsubayashi G-E (1983) Inorg Chim Acta 70:1

170. Oosawa Y, Urabe H, Saito T, Sasaki Y (1976) J Organomet Chem 122:113

171. Holy N, Deschler U, Schmidbaur H (1982) Chem Ber 115:1379

172. Usón R, Forniés J, Navarro R, Ortega AM (1987) J Organomet Chem 334:389

173. Usón R, Laguna A, Laguna M, Lázaro I, Jones PG (1987) Organometallics 6:2326

174. Gimeno MC, Jones PG, Laguna A, Laguna M, Lázaro I (1993) J Chem Soc Dalton Trans, p 2223

175. Gimeno MC, Jones PG, Laguna A, Villacampa MD (1995) J Chem Soc Dalton Trans, p 805 176. Schmidbaur H, Deschler U, Milewski-Mahrla B (1981) Angew Chem Int Ed Engl 20:586

177. Gong JK, Peters TB, Fanwick PE, Kubiak CP (1992) Organometallics 11:1392

178. Alcock NW, Pringle PG, Bergamini P, Sostero S, Traverso O (1990) J Chem Soc Dalton Trans, p 1553

179. Lin IJB, Lai HYC, Wu SC, Hwan L (1986) J Organomet Chem 306:C24

180. Lin IJB, Hwan L, Shy HC, Chen MC, Wang Y (1986) J Organomet Chem 315:135

181. Cheng MC, Peng SM, Lin IJB, Meng BHH, Liu CH (1987) J Organomet Chem 327:275

182. Lin IJB, Shy HC, Liu CW, Liu L-K, Yeh S-K (1990) J Chem Soc Dalton Trans, p 2509

183. Wu RF, Lin IJB Lee GH, Cheng MC, Wang Y (1990) Organometallics 9:126

184. Brauer DJ, Krüger C, Roberts PJ, Tsay Y-H (1974) Chem Ber 107:3706

185. Basset JM, Mandl JR, Schmidbaur H (1980) Chem Ber 113:1145

186. Vicente J, Chicote MT, Saura-Llamas I, López-Muñoz MJ, Jones PG (1990) J Chem Soc

Dalton Trans, p 3683

187. Hostetler MJ, Butts MD, Bergman RG (1992) Inorg Chim Acta 198-200:377

188. Schmidbaur H, Costa T, Milewski-Mahrla B (1981) Chem Ber 114:1428

189. Schmidbaur H, Costa T, Milewski-Mahrla B, Köhler FH, Tsay Y-H, Krüger C, Abart J,

Wagner FE (1982) Organometallics 1:1266 


\section{Ylide Ligands}

190. Fluck E, Bieger K, Heckmann G, Neumüller B (1993) J Organomet Chem 459:73

191. Falvello LR, Margalejo ME, Navarro R, Urriolabeitia EP (2003) Inorg Chim Acta 347:75

192. Schmidbaur H, Gasser O, Krüger C, Sekutowski JC (1977) Chem Ber 110:3517

193. Vicente J, Chicote MT, Saura-Llamas I, Jones PG, Meyer-Bäse K, Erdbrügger CF (1988)

Organometallics 7:997

194. Falvello LR, Fernández S, Navarro R, Rueda A, Urriolabeitia EP (1998) Inorg Chem 37:6007

195. Aitken RA, Karodia N, Lightfoot P (2000) J Chem Soc Perkin Trans 2, p 333

196. Lledós A, Carbó JJ, Urriolabeitia EP (2001) Inorg Chem 40:4913

197. Lledós A, Carbó JJ, Navarro R, Urriolabeitia EP (2004) Inorg Chim Acta 357:1444

198. Lledós A, Carbó JJ, Navarro R, Serrano E, Urriolabeitia EP (2004) Inorg Chem 43:7622

199. Nielsen DJ, Cavell KJ, Skelton BW, White AH (2001) Organometallics 20:995

200. Serrano E, Vallés C, Carbó JJ, Lledós A, Soler T, Navarro R, Urriolabeitia EP (2006)

Organometallics 25:4653

201. Serrano E, Soler T, Navarro R, Urriolabeitia EP (2008) J Mol Struc 890:57

202. Jiang F, Shapiro PJ, Fahs F, Twamley B (2003) Angew Chem Int Ed 42:2651

203. Schmidbaur H, Franke R (1973) Angew Chem Int Ed Engl 12:416

204. Schmidbaur H, Adlkofer J, Buchner W (1973) Angew Chem Int Ed Engl 12:415

205. Schmidbaur H, Franke R (1975) Inorg Chim Acta 13:85

206. Dudis DS, Fackler Jr JP (1985) Inorg Chem 24:3758

207. Raptis RG, Fackler Jr JP, Murray HH, Porter LC (1989) Inorg Chem 28:4057

208. Raptis RG, Porter LC, Emrich RJ, Murray HH, Fackler Jr JP (1990) Inorg Chem 29:4408

209. Neitling DC, Staples RJ, Fackler Jr JP (1997) Inorg Chim Acta 263:35

210. Méndez LA, Jiménez J, Cerrada E, Mohr F, Laguna M (2004) J Am Chem Soc 127:852

211. Schmidbaur H, Hartmann C, Reber G, Müller G (1987) Angew Chem Int Ed Engl 26:1146

212. Pan Q-J, Zhou X, Fu H-G, Zhang H-X (2008) Organometallics 27:2474

213. Vicente J, Chicote MT, Saura-Llamas I, Jones PG (1989) Organometallics 8:767

214. Vicente J, Chicote MT, Saura-Llamas I (1990) J Chem Soc Dalton Trans, p 1941

215. Vicente J, Chicote MT, Saura-Llamas I, López-Muñoz MJ, Jones PG (1990) J Chem Soc Dalton Trans, p 3683

216. Fackler Jr JP, Basil JD (1982) Organometallics 1:871

217. Murray HH, Fackler Jr JP, Trczinska-Bancroft B (1985) Organometallics 4:1633

218. Basil JD, Murray HH, Fackler Jr JP, Tocher J, Mazany AM, Trzcinska-Bancroft B, Knachel

H, Dudis D, Delord TJ, Marler D (1985) J Am Chem Soc 107:6908

219. Murray III HH, Fackler Jr JP, Porter LC, Mazany AM (1986) J Chem Soc Chem Commun, p 321

220. Murray HH, Fackler Jr JP, Mazany AM, Porter LC, Shain J, Falvello LR (1986) Inorg Chim Acta 114:171

221. Trzcinska-Bancroft B, Khan MNI, Fackler Jr JP (1988) Organometallics 7:993

222. Murray HH, Mazany AM, Fackler Jr JP (1985) Organometallics 4:154

223. Jandik P, Schubert U, Schmidbaur H (1982) Angew Chem Int Ed Engl 21:73; ibid 74

224. Murray HH, Fackler Jr JP, Mazany AM (1984) Organometallics 3:1310

225. Knachel HC, Dudis DS, Fackler Jr JP (1984) Organometallics 3:1312

226. Murray III HH, Fackler Jr JP, Tocher DA (1985) J Chem Soc Chem Commun, p 1278 


\section{Ylide Ligands}

227. Schmidbaur H, Hartmann C, Riede J, Huber B, Müller G (1986) Organometallics 5:1652

228. Fackler Jr JP, Trczinska-Bancroft B (1985) Organometallics 4:1891

229. Heinrich DD, Staples RJ, Fackler Jr JP (1995) Inorg Chim Acta 229:61

230. Knachel HC, Dettorre CA, Galaska HJ, Salupo TA, Fackler Jr JP, Murray HH (1987) Inorg Chim Acta 126:7

231. Bardají M, Cerrada E, Jones PG, Laguna A, Laguna M (1997) J Chem Soc Dalton Trans, p 2263

232. Cerrada E, Gimeno MC, Jiménez J, Laguna A, Laguna M, Jones PG (1994) Organometallics 13:1470

233. Usón R, Laguna A, Laguna M, Tartón MT, Jones PG (1988) J Chem Soc Chem Commun, p 740

234. Usón R, Laguna A, Laguna M, Jiménez J, Jones PG (1991) Angew Chem Int Ed Engl 30:198

235. Laguna A, Laguna M, Jiménez J, Lahoz FJ, Olmos E (1994) Organometallics 13:253

236. Mohr F, Sanz S, Tiekink ERT, Laguna M (2006) Organometallics 25:3084

237. Usón R, Laguna A, Laguna M, Jiménez J, Jones PG (1991) J Chem Soc Dalton Trans, p 1361

238. Fackler Jr JP, Porter LC (1986) J Am Chem Soc 108:2750

239. Findeis B, Contel M, Gade LH, Laguna M, Gimeno MC, Scowen IJ, McPartlin M (1997) Inorg Chem 36:2386

240. Bardají M, Gimeno MC, Jones PG, Laguna A, Laguna M (1994) Organometallics 13:3415

241. Bardají M, Jones PG, Laguna A, Laguna M (1995) Organometallics 14:1310

242. King C, Heinrich DD, Wang JC, Fackler Jr JP, Garzon G (1989) J Am Chem Soc 111:2300 